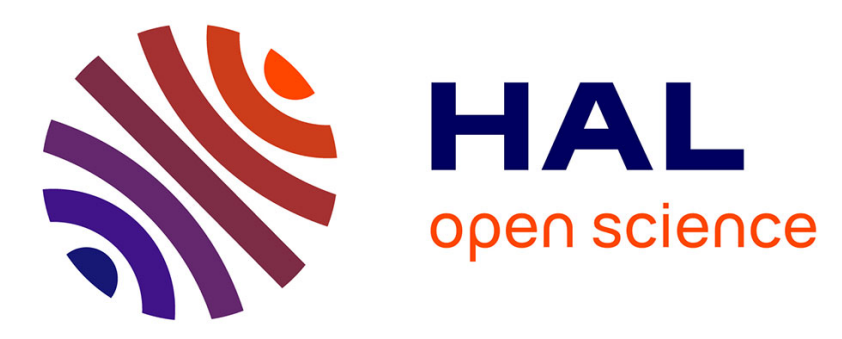

\title{
Continuous lipase-catalyzed production of pseudo-ceramides in a packed-bed bioreactor
}

Florian Le Joubioux, Nicolas Bridiau, Mehdi Sanekli, Marianne Graber, Thierry Maugard

\section{- To cite this version:}

Florian Le Joubioux, Nicolas Bridiau, Mehdi Sanekli, Marianne Graber, Thierry Maugard. Continuous lipase-catalyzed production of pseudo-ceramides in a packed-bed bioreactor. Journal of Molecular Catalysis B: Enzymatic, 2014, 109, pp.143-153. 10.1016/j.molcatb.2014.08.022 . hal-01070430

\author{
HAL Id: hal-01070430 \\ https://hal.science/hal-01070430
}

Submitted on 7 Oct 2014

HAL is a multi-disciplinary open access archive for the deposit and dissemination of scientific research documents, whether they are published or not. The documents may come from teaching and research institutions in France or abroad, or from public or private research centers.
L'archive ouverte pluridisciplinaire HAL, est destinée au dépôt et à la diffusion de documents scientifiques de niveau recherche, publiés ou non, émanant des établissements d'enseignement et de recherche français ou étrangers, des laboratoires publics ou privés. 
1 Continuous lipase-catalyzed production of pseudo-ceramides in a packed2 bed bioreactor

3 Florian Le Joubioux, Nicolas Bridiau*, Mehdi Sanekli, Marianne Graber, Thierry 4 Maugard

5

6 Equipe Approches Moléculaires, Environnement-Santé, UMR 7266 CNRS-ULR, LIENSs,

7 Université de La Rochelle, Avenue Michel Crépeau, 17042 La Rochelle, France.

8

9 *Author for correspondence (Fax: +33 546458265; E-mail: nicolas.bridiau@univ-lr.fr) 


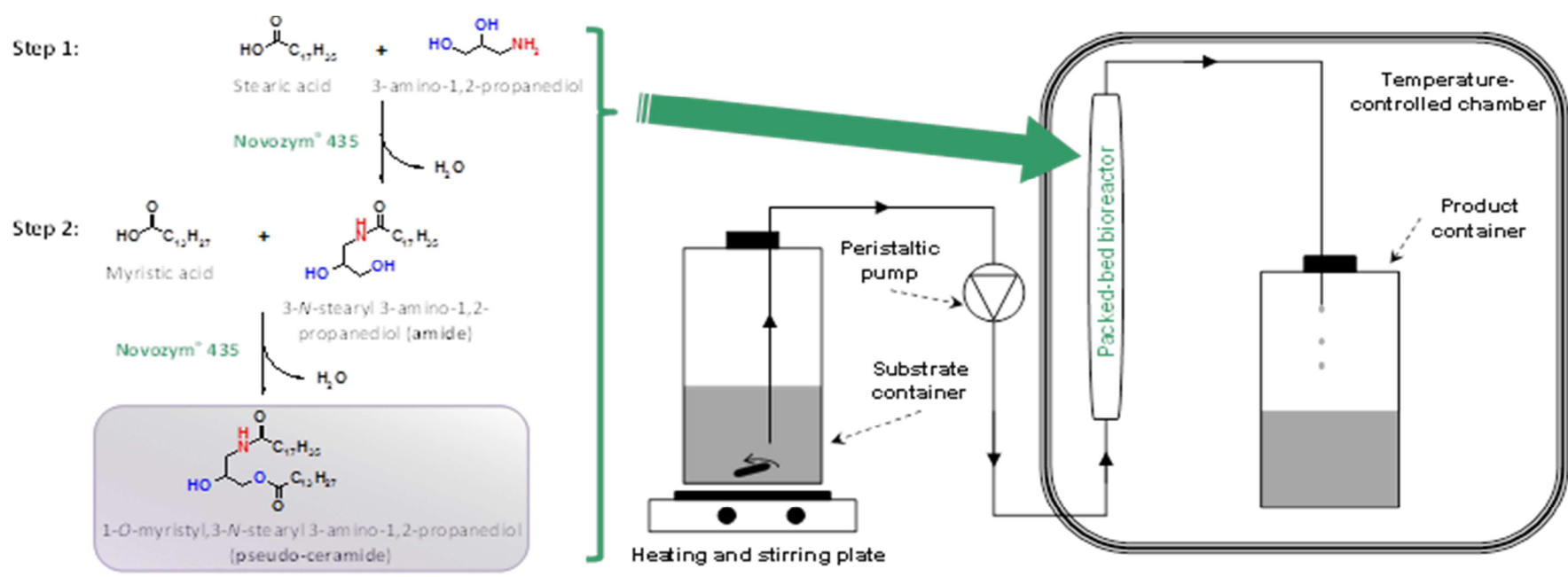




\section{Abstract}

Ceramides are spingolipid compounds that are very attractive as active components in both the pharmaceutical and the cosmetic industries. In this study, the synthesis of ceramide analogs, the so-called pseudo-ceramides, was carried out using for the first time a two-step continuous enzymatic process with immobilized Candida antarctica lipase B (Novozym ${ }^{\circledR}$ 435) in a packed-bed bioreactor. The first step involved the selective $\mathrm{N}$-acylation of 3 -amino1,2-propanediol using stearic acid as the first acyl donor (i). This was followed by the selective $O$-acylation of the $N$-stearyl 3-amino-1,2-propanediol synthesized in the first step, with myristic acid as the second acyl donor, to produce a N,O-diacyl 3-amino-1,2propanediol-type pseudo-ceramide, namely 1-O-myristyl,3- $N$-stearyl 3-amino-1,2propanediol (ii). The process was first optimized by evaluating the influences of three factors: feed flow rate, quantity of biocatalyst and substrate concentration. Under optimal conditions an amide synthesis yield of $92 \%$ and a satisfying production rate of almost $3.15 \mathrm{mmol} \mathrm{h}^{-1}$ $\mathrm{g}_{\text {biocatalyst }}^{-1}\left(1128 \mathrm{mg} \mathrm{h}^{-1} \mathrm{~g}_{\text {biocatalyst }}{ }^{-1}\right)$ were obtained. The second step, $\mathrm{N}$-acyl 3-amino-1,2propanediol $O$-acylation, was similarly optimized and in addition the effect of the substrate molar ratio was studied. Thus, an optimal pseudo-ceramide synthesis yield of $54 \%$ and a production rate of $0.46 \mathrm{mmol} \mathrm{h}^{-1} \mathrm{~g}_{\text {biocatalyst }}{ }^{-1}\left(261 \mathrm{mg} \mathrm{h}^{-1} \mathrm{~g}_{\text {biocatalyst }}{ }^{-1}\right)$ were reached at a 1:3 ratio of amide to fatty acid. In addition, it was demonstrated that this two-step process has great potential for the production of $\mathrm{N}, \mathrm{O}$-diacyl 3-amino-1,2-propanediol-type pseudo-ceramides on an industrial scale. It was shown in particular that Novozym ${ }^{\circledR} 435$ could be used for more than 3 weeks without a drop in the yield during the first step of 3-amino-1,2-propanediol $\mathrm{N}$ acylation, proving that this biocatalyst is very stable under these operational conditions. This factor would greatly reduce the need for biocatalyst replacement and significantly lower the associated cost. 
37 Keywords: pseudo-ceramide, biocatalysis, lipase, continuous bioprocess, packed-bed 38 bioreactor 


\section{Introduction}

Ceramides are natural compounds derived from the $N$-acylation of sphingosine and are key intermediates in the biosynthesis of all complex sphingolipids. Like their synthetic analogs, they have been widely used in the cosmetic and pharmaceutical industries. Indeed, due to their major role in preserving the water-retaining properties of the epidermis [1], ceramides have a wide range of commercial applications in the cosmetic industry as active ingredients included in hair and skin care products. Moreover, ceramides can be used as active components in dermatological therapy: they are effective in restoring the water content of dry skin and in relieving atopic eczema [2]. In addition, it has been demonstrated that they have commercial applications in the pharmaceutical industry as potential anti-viral or anti-tumor drugs [3, 4] and anti-oxidant stabilizers [5].

As a result of these numerous commercial applications, there is a growing interest in the development and optimization of new processes for ceramide synthesis. Ceramide synthesis is usually performed by acylation of the amino group of a sphingosine, a sphinganine or their derivatives [6-8]. However, due to the high cost of sphingoid bases, whose chemical synthesis is complex, other approaches have been developed to synthesize ceramide analogs, called pseudo-ceramides, by the selective acylation of multifunctional compounds like aminoalcohols. All these compounds are presently synthesized by chemical procedures which require fastidious steps of alcohol group protection and deprotection for the control of chemoselectivity, regioselectivity and stereoselectivity [6-10]. Moreover, these procedures often require high temperatures that may preclude the use of fragile molecules and may cause coloration of the end products. In addition, the coproduction of salts and the use of toxic solvents (dimethylformamide, methanol, etc.) that must be eliminated at the end of the reaction tend to increase the cost of the processes. 
In order to overcome these disadvantages, several studies focused on developing enzymatic syntheses of pseudo-ceramides through immobilized lipase-catalyzed acylation or transacylation reactions carried out in an organic solvent or in a solvent-free system [11-13]. Indeed, using lipases (E.C. 3.1.1.3) in the process can be both more effective, due to a higher selectivity, and more eco-compatible, due to the limited number of steps required for the synthesis [14-18]. Lipase-catalyzed acylation in organic media provides several advantages such as shifting the thermodynamic equilibrium toward synthesis rather than hydrolysis, increasing the solubility of non-polar substrates like fatty acids, eliminating side reactions, making enzyme recovery easier and increasing enzyme thermostability [19].

Various studies have been devoted to the lipase-catalyzed acylation of multi-functional molecules similar to the substrates used as precursors for the synthesis of pseudo-ceramides. These molecules have both amino and alcohol groups, such as ethanolamine, diethanolamine, 2-amino-1-butanol, 6-amino-1-hexanol, serine and other amino-alcohols of variable carbon chain length [20-28]. In such reactions, it has been shown that the lipases used can catalyze the chemoselective acylation of these substrates in a highly efficient and chemoselective manner. Some of these studies have already demonstrated the feasibility of selectively synthesizing pseudo-ceramide-type compounds using heterogeneous solvent-free media in a batch bioreactor, with productivity close to $15 \mathrm{~g}_{\text {pseudo-ceramide }} \mathrm{g}_{\text {biocatalyst }}{ }^{-1}[12,26]$. Based on these studies, lipases seem to be the ideal biocatalysts for the synthesis of pseudo-ceramide compounds.

On the other hand, despite the many synthetic processes that have already been developed, also in batch reactors [6-13, 29], ceramides are still not easy to produce for industrial applications. The price of the cheapest synthetic ceramide is close to $2000 € / \mathrm{kg}$, and ceramides with a fatty acid composition similar to that found in the skin cost several hundred thousand $€ / \mathrm{kg}$. So, it would be extremely beneficial to develop an alternative cost-efficient 
method to produce this valuable product with a high yield and productivity. In recent years, the use of continuous-flow technology has become an innovative, promising and attractive alternative for the highly selective production of pure chemical compounds with a good level of productivity. Packed-bed bioreactors are the most frequently used and the best continuous production systems. They offer several advantages over a batch reactor: they are easy to use, can be controlled and operated automatically, they reduce operating costs, provide a better control of the operating conditions and products, leading to a significant enhancement in the productivity of the biocatalyst and an improvement in quality (less secondary products) and yield $[30,31]$. Such systems have a low reactor volume due to the high enzyme/substrate ratio maintained in the catalytic bed. In addition, the enzyme/substrate ratio is higher in packed-bed bioreactors than in conventional batch bioreactors, thus shortening the reaction time and potentially limiting side reactions, thereby improving selectivity.

Starting from this overview, the aim of our work was to develop for the first time a continuous process for the efficient enzymatic production of 1-O,3- $N$-diacyl 3-amino-1,2propanediol-type pseudo-ceramides. These diacylated derivatives of 3-amino-1,2-propanediol have been considered in various studies as pseudo-ceramides for two reasons: i) their structure includes a polar head, two lipophilic carbon chains and an amide bond, and is thus very close to natural ceramide structure; ii) they have been demonstrated to have restructuring effects very similar to those of natural ceramides at the level of the uppermost skin layer, the socalled stratum corneum $[12,26,32]$.

The process developed in this work was performed using a packed-bed bioreactor containing immobilized Candida antarctica lipase B (Novozym $\left.^{\circledR} 435\right)$. In order to control the chemoselectivity of the reaction, the process was divided into two steps (scheme 1): $N$-stearyl 3-amino-1,2-propanediol 3a (amide) was obtained in the first step from the $\mathrm{N}$-acylation of 3amino-1,2-propanediol 1 using stearic acid 2a as a first acyl donor. In the second step, 1-O- 
myristyl,3- $N$-stearyl 3-amino-1,2-propanediols 4 (pseudo-ceramide) was produced from the $O$-acylation of the $N$-stearyl 3-amino-1,2-propanediol 3a (amide) produced in the first step using myristic acid $\mathbf{2} \mathbf{b}$ as a second acyl donor.

\section{Scheme 1.}

\section{Material and methods}

\subsection{Enzymes and chemicals}

Novozym $^{\circledR} 435$ (immobilized Candida antarctica lipase B) was kindly provided by Novozymes A/S, Bagsvaerd, Denmark. ( \pm )-3-amino-1,2-propanediol (97\%), lauric acid ( $\geq 99 \%)$, stearic acid (95\%), linoleic acid ( $\geq 99 \%)$ and tert-amyl alcohol (99\%) were purchased from Sigma Aldrich (St Louis, USA) while myristic acid ( $\geq 98 \%)$ and oleic acid (97\%) were purchased from Fluka (St Quentin-Fallavier, Switzerland). All chemicals were dried over molecular sieves. Pure water was obtained via a Milli-Q system (Millipore, France). Acetonitrile, methanol, $n$-hexane and chloroform were purchased from Carlo ERBA (Val-deReuil, France).

2.2. Continuous process using a packed-bed bioreactor system for the Novozym ${ }^{\circledR}$ 435-catalyzed synthesis of 1-O,3-N-diacyl 3-amino-1,2-propanediol-type pseudo-ceramides

\subsubsection{Packed-bed bioreactor system}

Fig. 1 schematically shows the packed-bed bioreactor system used for the continuous two-step enzymatic synthesis of 1-O,3- $\mathrm{N}$-diacyl 3-amino-1,2-propanediol-type pseudo-ceramides catalyzed by immobilized Candida antarctica lipase B (Novozym $\left.{ }^{\circledR} 435\right)$ (scheme 1). For each step, the reaction mixture (substrates and solvent) was first homogenized for $15 \mathrm{~min}$ at $55^{\circ} \mathrm{C}$ 
while stirring at $250 \mathrm{rpm}$. The process was then started by percolating the reaction mixture into a column packed with Novozym ${ }^{\circledR} 435$ by means of a peristaltic pump (Minipuls Evolution Peristaltic Pump from Gilson Inc., USA). Several stainless steel columns of variable length and an inner diameter of $5 \mathrm{~mm}$ were used at the laboratory scale, while one $125 \mathrm{~mm}$ long column with a $10 \mathrm{~mm}$ inner diameter and a second that was $5 \mathrm{~mm}$ in length with an inner diameter of $50 \mathrm{~mm}$ were used to scale-up the reactor design. Throughout the process, the reaction medium leaving the bioreactor was continuously pooled into a product container which, together with the column packed with Novozym ${ }^{\circledR} 435$, was placed in a temperaturecontrolled chamber at $55^{\circ} \mathrm{C}$ to promote the synthesis reaction and ensure the solubility of the acylated products. Each step was carried out until the substrate container was empty, indicating the end of the process. The concentration of the remaining substrates and acylated products in the product container were then determined by LC/MS-ESI analysis.

\section{Fig. 1}

\subsubsection{First step: $N$-acylation of 3-amino-1,2-propanediol}

In the first step, the reaction mixture contained 3-amino-1,2-propanediol 1, a fatty acid (stearic acid $\mathbf{2 a}$, myristic acid $\mathbf{2 b}$, lauric acid $\mathbf{2 c}$, oleic acid $\mathbf{2 d}$ or linoleic acid $\mathbf{2 e}$ ), which was used as an acyl donor, and a tert-amyl alcohol $/ n$-hexane $(50: 50 \mathrm{v} / \mathrm{v})$ mixture used as the reaction solvent.

\subsubsection{Second step: O-acylation of $N$-acyl 3-amino-1,2-propanediol}

In the second step, the reaction mixture contained the $N$-stearyl 3-amino-1,2-propanediol 3a produced during the first step, myristic acid $\mathbf{2 b}$, which was used as an acyl donor and a tertamyl alcohol $/ n$-hexane (50:50 v/v) mixture used as the reaction solvent.

\subsection{HPLC/MS analysis}


To monitor the reaction, a $500 \mu 1$ sample was taken from the product container when the continuous process was complete, after $1 \mathrm{~h}$ of reaction. The study of the operational stability of Novozym $^{\circledR} 435$ in the continuous packed-bed bioreactor was carried out in a slightly different manner: $500 \mu \mathrm{l}$ samples were taken from the packed-bed output at different times over a 3-week period. In each case, $500 \mu \mathrm{l}$ of a methanol/chloroform (50:50 v/v) mixture were added to each sample in order to homogenize the reaction medium at room temperature. Structural and quantitative analyses of the reaction products were then conducted on these samples using a LC/MS-ES system from Agilent (1100 LC/MSD Trap mass spectrometer VL) with a C18 Prontosil 120-5-C18-AQ reversed-phase column $(250 \times 4 \mathrm{~mm}, 5 \mu \mathrm{m}$; Bischoff Chromatography, Germany). The elution of the reaction samples was carried out at room temperature and at a flow rate of $1 \mathrm{ml} \mathrm{min}^{-1}$ using a gradient that was derived from two eluent mixtures (Table 1). The products were detected and quantified by differential refractometry and UV detection at $210 \mathrm{~nm}$. Quantification was performed against external calibration lines prepared using the appropriate acylated products as standards. These standards were synthesized using operating conditions in which only a specific standard could be formed using a given acyl donor, then purified and structurally characterized. Low-resolution mass spectral analyses were obtained by electrospray in the positive detection mode. Nitrogen was used as the drying gas at $151 \mathrm{~min}^{-1}, 350{ }^{\circ} \mathrm{C}$ and at a nebulizer pressure of 4 bars. The scan range was $50-1000 \mathrm{~m} / \mathrm{z}$ using five averages and $13,000 \mathrm{~m} / \mathrm{z}$ per second resolution. The capillary voltage was 4000 V. Processing was done offline using HP Chemstation software.

\section{Table 1}

\subsection{Purification and characterization of reaction products}

The reaction products were purified with a preparative HPLC system from Agilent (1200 LC/MSD) using a ProntoPrep C18 reversed-phase column $(250 \times 20 \mathrm{~mm}, 10 \mu \mathrm{m}$; Bischoff 
Chromatography, Germany) eluted according to the gradient given in Table 1, at room temperature and at a flow rate of $5 \mathrm{ml} \mathrm{min}{ }^{-1}$. The purified products were then characterized by ${ }^{1} \mathrm{H}$ NMR and infrared (IR) spectroscopy. The ${ }^{1} \mathrm{H}$ NMR chemical shift values were recorded on a JEOL-JNM LA400 spectrometer (400 MHz), with tetramethylsilane as an internal reference. The samples were studied as solutions in $\mathrm{CDCl}_{3}$. IR spectra were recorded from 400 to $4000 \mathrm{~cm}^{-1}$ with a resolution of $4 \mathrm{~cm}^{-1}$ using a 100 ATR spectrometer (Perkin-Elmer, United States).

\subsubsection{N-stearyl 3-amino-1,2-propanediol $3 a$}

$\mathrm{m} / \mathrm{z}\left(\mathrm{LR}-\mathrm{ESI}^{+}\right) \mathrm{C}_{21} \mathrm{H}_{44} \mathrm{NO}_{3}\left(\mathrm{M}+\mathrm{H}^{+}\right)$, found: 358.2, calculated for: 358.58. IR $v_{\max }\left(\mathrm{cm}^{-1}\right): 3312(\mathrm{O}-$ $\mathrm{H}$, alcohol and $\mathrm{N}-\mathrm{H}$, amide), 2800-3000 ( $\mathrm{CH}$ of stearyl chain), $1633(\mathrm{C}=\mathrm{O}$, amide), $1544(\mathrm{~N}-\mathrm{H}$, amide). ${ }^{1} \mathrm{H}$ NMR (400 MHz, $\left.\mathrm{CDCl}_{3}, \delta \mathrm{ppm}\right): \delta 0.88\left(\mathrm{t}, 3 \mathrm{H}, J=6.03 \mathrm{~Hz},-\mathrm{CH}_{2}-\mathrm{C}_{3}\right), 1.25(\mathrm{~m}, 28 \mathrm{H}$, $\mathrm{CH}_{2}$ - of stearyl chain), 1.63 (m, $2 \mathrm{H},-\mathrm{CH}_{2}-\mathrm{CH}_{2}-\mathrm{CO}-\mathrm{NH}$ - of stearyl chain), 2.21 (t, $2 \mathrm{H}, J=7.57 \mathrm{~Hz}$, $\mathrm{CH}_{2}-\underline{\mathrm{C}}_{2}-\mathrm{CO}-\mathrm{NH}-$ of stearyl chain), 3.42 (m, 2H, $\left.-\mathrm{CH}-\underline{\mathrm{C}}_{2}-\mathrm{OH}\right), 3.54$ (m, 2H,-CH-C $\left.\underline{H}_{2}-\mathrm{NH}-\right), 3.75$ (m, 1H, -CH-), 5.84 (s, 1H, -NH-).

\subsubsection{N-myristyl 3-amino-1,2-propanediol $\mathbf{3 b}$}

m/z (LR-ESI $\left.{ }^{+}\right) \mathrm{C}_{17} \mathrm{H}_{36} \mathrm{NO}_{3}\left(\mathrm{M}+\mathrm{H}^{+}\right)$, found: 302.1, calculated for: 302.47. IR $v_{\max }\left(\mathrm{cm}^{-1}\right): 3298(\mathrm{O}-$ $\mathrm{H}$, alcohol and N-H, amide), 2800-3000 ( $\mathrm{CH}$ of myristyl chain), 1634 (C=O, amide), 1546 (N-H, amide). ${ }^{1} \mathrm{H}$ NMR (400 MHz, $\left.\mathrm{CDCl}_{3}, \delta \mathrm{ppm}\right): \delta 0.88$ (t, 3H, $\left.J=6.55 \mathrm{~Hz},-\mathrm{CH}_{2}-\mathrm{C}_{3}\right), 1.25(\mathrm{~m}, 20 \mathrm{H}$, $\mathrm{CH}_{2}$ - of myristyl chain), 1.63 (m, $2 \mathrm{H},-\mathrm{C}_{2}-\mathrm{CH}_{2}-\mathrm{CO}-\mathrm{NH}$ - of myristyl chain), 2.21 (t, $2 \mathrm{H}, J=8 \mathrm{~Hz}$, $\mathrm{CH}_{2}-\underline{\mathrm{C}}_{2}-\mathrm{CO}-\mathrm{NH}$ - of myristyl chain), 3.42 (m, 2H, $\left.-\mathrm{CH}-\underline{\mathrm{C}}_{2}-\mathrm{OH}\right), 3.56$ (m, 2H,-CH-C $\left.\underline{H}_{2}-\mathrm{NH}-\right), 3.76$ (m, 1H, -CH-), 5.88 (s, 1H, -NH-).

\subsubsection{N-lauryl 3-amino-1,2-propanediol 3c}

m/z (LR-ESI $\left.{ }^{+}\right) \mathrm{C}_{15} \mathrm{H}_{32} \mathrm{NO}_{3}\left(\mathrm{M}+\mathrm{H}^{+}\right)$, found: 274.2, calculated for: 274.43. IR $v_{\text {max }}\left(\mathrm{cm}^{-1}\right): 3307(\mathrm{O}-$ H, alcohol and N-H, amide), 2800-3000 ( $\mathrm{CH}$ of lauryl chain), 1631 (C=O, amide), 1545 (N-H, amide). ${ }^{1} \mathrm{H}$ NMR (400 MHz, $\left.\mathrm{CDCl}_{3}, \delta \mathrm{ppm}\right): \delta 0.88\left(\mathrm{t}, 3 \mathrm{H}, J=7 \mathrm{~Hz},-\mathrm{CH}_{2}-\mathrm{C}_{3}\right), 1.26\left(\mathrm{~m}, 16 \mathrm{H},-\mathrm{CH}_{2}\right.$ - of lauryl 
chain), 1.62 (m, 2H, - $\mathrm{CH}_{2}-\mathrm{CH}_{2}-\mathrm{CO}-\mathrm{NH}-$ of lauryl chain), 2.23 (t, $2 \mathrm{H}, J=7.23 \mathrm{~Hz},-\mathrm{CH}_{2}-\mathrm{CH}_{2}-\mathrm{CO}-\mathrm{NH}-$ of lauryl chain), 3.43 (m, 2H, $\left.-\mathrm{CH}-\underline{\mathrm{CH}}_{2}-\mathrm{OH}\right), 3.56$ (m, 2H,-CH-C $\left.\underline{\mathrm{H}}_{2}-\mathrm{NH}-\right), 3.76$ (m, 1H, -CH-), 5.92 (s, 1H, -NH-).

\subsubsection{N-oleyl 3-amino-1,2-propanediol 3d}

m/z (LR-ESI $\left.{ }^{+}\right) \mathrm{C}_{21} \mathrm{H}_{42} \mathrm{NO}_{3}\left(\mathrm{M}+\mathrm{H}^{+}\right)$, found: 356.2, calculated for: 356.57. IR $v_{\max }\left(\mathrm{cm}^{-1}\right): 3342(\mathrm{O}-$ $\mathrm{H}$, alcohol and $\mathrm{N}-\mathrm{H}$, amide), 2800-3000 ( $\mathrm{CH}$ of oleyl chain), 1632(C=O, amide), 1546 (N-H, amide). ${ }^{1} \mathrm{H}$ NMR $\left(400 \mathrm{MHz}, \mathrm{CDCl}_{3}, \delta \mathrm{ppm}\right): \delta 0.88\left(\mathrm{t}, 3 \mathrm{H}, J=6.55 \mathrm{~Hz},-\mathrm{CH}_{2}-\mathrm{C}_{3}\right), 1.27\left(\mathrm{~m}, 12 \mathrm{H}, \mathrm{CH}-\mathrm{CH}_{2^{-}}\right.$ $\underline{\mathrm{CH}_{2}}-\underline{\mathrm{CH}_{2}}-\underline{\mathrm{CH}_{2}} \underline{-\mathrm{CH}_{2}} \underline{-\mathrm{CH}_{2}} \underline{-\mathrm{CH}_{2}}-\mathrm{CH}_{3}$ of oleyl chain), 1.31 (m, 8H, CH-CH $-\underline{\mathrm{CH}_{2}} \underline{-\mathrm{CH}_{2}} \underline{-\mathrm{CH}_{2}} \underline{-\mathrm{CH}_{2}}-\mathrm{CH}_{2}-$ $\mathrm{CH}_{2}-\mathrm{CO}-\mathrm{NH}$ of oleyl chain), $1.64\left(\mathrm{~m}, 2 \mathrm{H},-\mathrm{CH}_{2}-\mathrm{CH}_{2}-\mathrm{CO}-\mathrm{NH}-\right.$ of oleyl chain), 2.01 (m, $4 \mathrm{H},-\underline{\mathrm{CH}}_{2}-$ $\mathrm{CH}=\mathrm{CH}-\mathrm{CH}_{2^{-}}$of oleyl chain), $2.22\left(\mathrm{t}, 2 \mathrm{H}, J=7.24 \mathrm{~Hz},-\mathrm{CH}_{2}-\mathrm{CH}_{2}-\mathrm{CO}-\mathrm{NH}-\right.$ of oleyl chain), 3.41 (m, $\left.2 \mathrm{H},-\mathrm{CH}-\mathrm{CH}_{2}-\mathrm{OH}\right), 3.53\left(\mathrm{~m}, 2 \mathrm{H},-\mathrm{CH}-\mathrm{CH}_{2}-\mathrm{NH}-\right), 3.72(\mathrm{~m}, 1 \mathrm{H},-\mathrm{CH}-), 5.34$ (m, 2H, - $\mathrm{CH}_{2}-\underline{\mathrm{CH}}=\mathrm{CH}-$ $\mathrm{CH}_{2}$ - of oleyl chain), 5.94 (s, 1H, -NH-).

\subsubsection{N-linoleyl 3-amino-1,2-propanediol 3e}

m/z (LR-ESI $\left.{ }^{+}\right) \mathrm{C}_{21} \mathrm{H}_{40} \mathrm{NO}_{3}\left(\mathrm{M}+\mathrm{H}^{+}\right)$, found: 354.1, calculated for: 354.56. IR $v_{\text {max }}\left(\mathrm{cm}^{-1}\right): 3303(\mathrm{O}-$ $\mathrm{H}$, alcohol and N-H, amide), 2800-3000 ( $\mathrm{CH}$ of linoleyl chain), 1634 (C=O, amide), $1548(\mathrm{~N}-\mathrm{H}$, amide).

\subsubsection{1-O-myristyl,3-N-stearyl 3-amino-1,2-propanediol 4}

m/z (LR-ESI $\left.{ }^{+}\right) \mathrm{C}_{35} \mathrm{H}_{70} \mathrm{NO}_{4} \mathrm{Na}\left(\mathrm{M}+\mathrm{Na}^{+}\right)$, found: 590.2, calculated for: 590.94. IR $v_{\max }\left(\mathrm{cm}^{-1}\right): 3651$ (O-H, alcohol), 3200-3400 (O-H, alcohol and N-H, amide), 2800-3000 (CH of stearyl and myristyl chains), 1720 ( $\mathrm{C}=\mathrm{O}$, ester), $1650\left(\mathrm{C}=\mathrm{O}\right.$, amide), $1546\left(\mathrm{~N}-\mathrm{H}\right.$, amide). ${ }^{1} \mathrm{H}$ NMR (400 MHz, $\mathrm{CDCl}_{3}, \delta$ ppm): $\delta 0.88\left(\mathrm{t}, 6 \mathrm{H}, J=6.3 \mathrm{~Hz}, 2 \mathrm{x}-\mathrm{CH}_{2}-\mathrm{C}_{3}\right), 1.25\left(\mathrm{~m}, 48 \mathrm{H},-\mathrm{CH}_{2}-\right.$ of stearyl and myristyl chains), $1.62\left(\mathrm{~m}, 4 \mathrm{H}, 2 \mathrm{x}-\mathrm{CH}_{2}-\mathrm{CH}_{2}-\mathrm{CO}-\right.$ of stearyl and myristyl chains), $2.21\left(\mathrm{t}, 2 \mathrm{H}, J=7.11 \mathrm{~Hz},-\mathrm{CH}_{2}-\mathrm{CH}_{2}-\right.$ CO-O- of myristyl chain), 2.34 (t, $2 \mathrm{H}, J=7.78 \mathrm{~Hz},-\mathrm{CH}_{2}-\mathrm{CH}_{2}-\mathrm{CO}-\mathrm{NH}-$ of stearyl chain), 3.53 (dd, $1 \mathrm{H}$, $\left.J=4.88 \mathrm{~Hz}, J=14.15 \mathrm{~Hz},-\mathrm{CH}-\underline{\mathrm{C}}_{2}-\mathrm{NH}-\right), 3.56\left(\mathrm{dd}, 1 \mathrm{H}, J=4.88 \mathrm{~Hz}, J=14.15 \mathrm{~Hz},-\mathrm{CH}-\mathrm{CH}_{2}-\mathrm{NH}-\right), 3.94$ 
$(\mathrm{m}, 1 \mathrm{H},-\mathrm{CH}-), 4.05\left(\mathrm{dd}, 1 \mathrm{H}, J=5.49 \mathrm{~Hz}, J=10.98 \mathrm{~Hz},-\mathrm{CH}-\underline{C H}_{2}-\mathrm{O}-\right), 4.15(\mathrm{dd}, 1 \mathrm{H}, J=5.12 \mathrm{~Hz}, J=$ $\left.11.46 \mathrm{~Hz},-\mathrm{CH}-\underline{\mathrm{C}}_{2}-\mathrm{O}-\right), 5.95$ (t, $\left.1 \mathrm{H}, J=5.2 \mathrm{~Hz},-\mathrm{NH}-\right)$.

\section{Results and discussion}

The continuous enzymatic synthesis of 1-O,3- $\mathrm{N}$-diacyl 3-amino-1,2-propanediol-type pseudoceramides catalyzed by immobilized Candida antarctica lipase B (Novozym ${ }^{\circledR} 435$ ) was conducted in a packed-bed bioreactor system (Scheme 1, Fig. 1) in two steps. $N$-acyl 3-amino1,2-propanediol (amide) was obtained from the $\mathrm{N}$-acylation of 3-amino-1,2-propanediol 1 in the first step (step 1). In the second step (step 2), 1-O,3- $N$-diacyl 3-amino-1,2-propanediol (pseudo-ceramide) was then produced from the $\mathrm{O}$-acylation of the $\mathrm{N}$-acyl 3-amino-1,2propanediol (amide) synthesized in step 1. In order to promote both the synthesis and the solubility of the products, all the reactions were carried out at $55^{\circ} \mathrm{C}$.

A tert-amyl alcohol $/ n$-hexane mixture $(50: 50 \mathrm{v} / \mathrm{v})$ was chosen as the reaction solvent on the basis of previous work that demonstrated the capacity of these two solvents to promote the selective Novozym ${ }^{\circledR} 435$-catalyzed synthesis of amide and amido-ester products starting from various amino-alcohols as substrates [33].

Regarding the choice of the appropriate acyl donors to use at each step of the process, we decided first to base our selection on the structure of natural ceramides, which are mostly composed of long-chain saturated fatty acids. C18:0 fatty acids are indeed one of the most abundant fatty acids incorporated in the natural ceramides located in the outer layer of the skin, namely the stratum corneum [34-36]. For this reason we chose stearic acid 2a as the first acyl donor for step 1 ( $N$-acylation). Myristic acid $\mathbf{2 b}$, on the other hand, was chosen as the second acyl donor for step 2 ( $O$-acylation) to mimic the structure of the sphingoid bases found in natural ceramides from human skin (18 carbons for the most common sphingoid bases) [34-37]. To achieve this, the C14 carbon chain of myristic acid $\mathbf{2} \mathbf{b}$ was conjugated to 
the C3 carbon chain of 3-amino-1,2-propanediol 1 via an ester bond, giving a chain of 18 atoms with 17 carbons and 1 oxygen.

In a preliminary study, the two reactions were conducted under stoichiometric conditions using a substrate concentration of $100 \mathrm{mM}$ at a flow rate of $250 \mu 1 \mathrm{~min}^{-1}$ for step 1 , and a substrate concentration of $50 \mathrm{mM}$ at a flow rate of $125 \mu 1 \mathrm{~min}^{-1}$ for step 2 . Two stainless steel columns, one $95 \mathrm{~mm}$ in length with an inner diameter of $5 \mathrm{~mm}$, the other $145 \mathrm{~mm}$ in length with an inner diameter of $5 \mathrm{~mm}$, were packed with 430 and $875 \mathrm{mg}$ of Novozym ${ }^{\circledR} 435$ to constitute the catalytic beds for steps 1 and 2, respectively. After production under these nonoptimized conditions and purification, the products of each step were analyzed by IR and NMR spectroscopy. It was thus demonstrated that $N$-stearyl-3-amino-1,2-propanediol (amide 3a) was selectively produced at step 1 with a $76 \%$ yield and a production rate of 2.65 mmol $\mathrm{h}^{-1} \mathrm{~g}_{\text {biocatalyst }}{ }^{-1}\left(948 \mathrm{mg} \mathrm{h}^{-1} \mathrm{~g}_{\text {biocatalyst }}{ }^{-1}\right)$, while 1-O-myristyl,3- $N$-stearyl 3-amino-1,2propanediol (amido-ester 4) was produced at step 2, also selectively, with a $24 \%$ yield and a production rate of $0.1 \mathrm{mmol} \mathrm{h}^{-1} \mathrm{~g}_{\text {biocatalyst }}{ }^{-1}\left(58 \mathrm{mg} \mathrm{h}^{-1} \mathrm{~g}_{\text {biocatalyst }}{ }^{-1}\right)$. Indeed, no secondary product was detected for both steps. These results confirmed that step 1 is exclusively chemoselective for the $\mathrm{N}$-acylation of 3-amino-1,2-propanediol while step 2 is regioselective for the $O$-acylation of the primary alcohol function in position 1 . This corroborates the results obtained in a preliminary study which demonstrated the same selectivity for the two steps of the same process performed in a batch bioreactor (data not shown). Furthermore, these results are also in agreement with data already published, regarding the Novozym ${ }^{\circledR} 435$-catalyzed acylation of substrates structurally related to 3-amino-1,2-propanediol, carried out in similar organic solvents. These works were performed in a batch bioreactor using myristic acid as the acyl donor. First, the acylation of alaninol (2-amino-1-propanol) demonstrated the chemoselectivity for the $\mathrm{N}$-acylation, with the production of 2- $\mathrm{N}$-myristyl 2-amino-1-propanol only [27, 28], which is similar to the results obtained at step 1 of the continuous process. 
Secondly, the $O$-acylation of 1,2-propanediol was regioselective for the primary alcohol function in position 1 [28].

All these preliminary results showed that the selectivity of both steps of the process does not need to be controlled during its implementation. Nevertheless, despite being encouraging in terms of yield and production rate, they were not satisfying enough to envisage scaling up the process. Starting from this fact, we thus concentrated our efforts on optimizing both steps of the process. For that purpose, the influences of feed flow rate, quantity of biocatalyst, substrate concentration and substrate molar ratio were examined. These parameters are likely to have a significant effect on the yield and productivity of a continuous enzymatic process.

\subsection{Optimization of the process}

\subsubsection{Effect of feed flow rate}

The feed flow rate plays an essential role in the continuous operation because it is related to the residence time of the substrates and products in the column. In order to achieve a higher synthesis yield for each step of the process, a sufficient residence time is needed to ensure that the substrate is interacting with the enzyme's active site. We thus examined the effect of feed flow rate on both synthesis yield and production rate (Fig. 2).

Fig. 2

During the first step, the flow rate was varied from 125 to $1000 \mu 1 \mathrm{~min}^{-1}$ (Fig. 2A). The amide 3a yield was relatively constant and close to $80 \%$ from 125 to $500 \mu 1 \mathrm{~min}^{-1}$. In parallel, the amide 3a production rate was shown to increase to a maximum value close to $6 \mathrm{mmol} \mathrm{h}^{-1}$ g biocatalyst $^{-1}\left(2145 \mathrm{mg} \mathrm{h}^{-1} \mathrm{~g}_{\text {biocatalyst }}{ }^{-1}\right)$. On the other hand, the amide yield and production

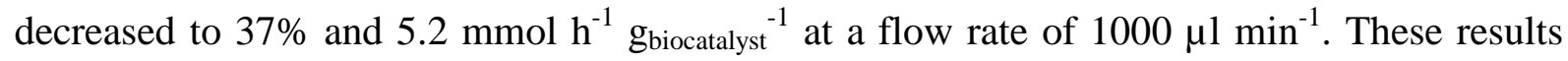
could be explained by the reduction in the substrate residence time within the packed-bed bioreactor, which was very likely caused by the increase in flow rate. Thus, at $1000 \mu 1 \mathrm{~min}^{-1}$, 
the residence time was probably not sufficient for the $N$-acylation reaction to reach thermodynamic equilibrium, which resulted in a lower yield. From these results, $500 \mu 1 \mathrm{~min}^{-1}$ was considered as the optimum flow rate for step 1.

During the second step, the flow rate was varied from 125 to $500 \mu 1 \mathrm{~min}^{-1}$ (Fig. 2B). Again, a relatively constant yield of pseudo-ceramide 4 of roughly $25 \%$ was obtained using flow rates within this range, with a maximum yield of $30 \%$ at a flow rate of $250 \mu 1 \mathrm{~min}^{-1}$. The reduction in the substrate residence time in the packed-bed bioreactor caused by the increase in the flow rate thus had no effect on the yield, as was already observed for the first step. In contrast, the production rate was shown to increase in conjunction with the faster flow rate, reaching a maximum value of $0.38 \mathrm{mmol} \mathrm{h}^{-1} \mathrm{~g}_{\text {biocatalyst }}{ }^{-1}$ at a flow rate of $500 \mu \mathrm{min}^{-1}$. However, this flow rate gave the lowest yield (22\%). For this reason $250 \mu 1 \mathrm{~min}^{-1}$ was taken as a compromise optimum flow rate value to achieve both the higher yield of $30 \%$ and a good production rate of $0.26 \mathrm{mmol} \mathrm{h}^{-1} \mathrm{~g}_{\text {biocatalyst }}{ }^{-1}\left(148 \mathrm{mg} \mathrm{h}^{-1} \mathrm{~g}_{\text {biocatalyst }}{ }^{-1}\right)$ in the second step.

\subsubsection{Effect of the quantity of biocatalyst}

The effect of the quantity of biocatalyst on both yield and production was investigated using various quantities of Novozym ${ }^{\circledR} 435$ packed into the packed-bed continuous reactor (Fig. 3).

\section{Fig. 3}

During the first step, the quantity of biocatalyst was varied from 215 to $1800 \mathrm{mg}$ (Fig. 3A). The lowest biocatalyst quantity of $215 \mathrm{mg}$ resulted in the lowest amide 3a yield obtained in this study (17\%). Starting from this value, the amide yield increased as a function of the quantity of biocatalyst rising to $87 \%$ for $875 \mathrm{mg}$ of Novozym ${ }^{\circledR} 435$. Nevertheless, when the quantity of biocatalyst was doubled (1800 mg), the amide 3a yield did not exceed $85 \%$. From these results, we concluded that the thermodynamic equilibrium of the reaction was already attained at $875 \mathrm{mg}$ of biocatalyst. In parallel, amide 3a production dramatically increased 
within the range $215-430 \mathrm{mg}$, rising to $1.38 \mathrm{mmol} \mathrm{h}^{-1} \mathrm{~g}_{\text {biocatalyst }}{ }^{-1}\left(493 \mathrm{mg} \mathrm{h}^{-1} \mathrm{~g}_{\text {biocatalyst }}{ }^{-1}\right)$, whereas the yield did not exceed $79 \%$ and thermodynamic equilibrium was not reached. The optimum quantity of biocatalyst for this step thus seems to be $875 \mathrm{mg}$ because this represents the best compromise between a high amide yield of $87 \%$ and the low cost of Novozym ${ }^{\circledR} 435$, despite the non-optimal production rate.

During the second step, the quantity of biocatalyst was varied from 430 to $2700 \mathrm{mg}$ (Fig. 3B). There was a degree of similarity in terms of the change in both the yield and the production rate of pseudo-ceramide $\mathbf{4}$ and amide $3 \mathbf{a}$. The yield of pseudo-ceramide $\mathbf{4}$ increased to $24 \%$ when the quantity of biocatalyst was increased from $430 \mathrm{mg}$ to $875 \mathrm{mg}$ but it did not exceed $25 \%$ when the quantity of Novozym ${ }^{\circledR} 435$ was doubled $(1800 \mathrm{mg})$. From these results we concluded that the thermodynamic equilibrium of the reaction had already been reached at $875 \mathrm{mg}$ of biocatalyst, as highlighted for the first step of $N$-acylation. In parallel, the production rate of pseudo-ceramide 4 continuously decreased as the quantity of biocatalyst was increased, falling from an initial rate of $0.18 \mathrm{mmol} \mathrm{h}^{-1} \mathrm{~g}_{\text {biocatalyst }}{ }^{-1}\left(102 \mathrm{mg} \mathrm{h}^{-1} \mathrm{~g}_{\text {biocatalyst }}{ }^{-1}\right)$ to barely $0.02 \mathrm{mmol} \mathrm{h}^{-1} \mathrm{~g}_{\text {biocatalyst }}{ }^{-1}$ for a $16 \%$ yield with $2700 \mathrm{mg}$ of Novozym ${ }^{\circledR} 435$. This loss of both yield and productivity may be explained by the fact that step 2 of pseudo-ceramide synthesis consists in a reverse hydrolysis and is consequently accompanied by the production of water molecules that gradually accumulate in the reaction medium. So, by increasing the amount of biocatalyst, a greater quantity of synthesis product (pseudo-ceramide) and water molecules is produced which are then in contact with the biocatalyst, resulting in competition between the pseudo-ceramide hydrolysis reactions. For this reason the decrease in both the yield and the production rate of pseudo-ceramide 4, observed when using a large quantity of immobilized lipase, may indicate that pseudo-ceramide hydrolysis is under thermodynamic control while pseudo-ceramide synthesis is under kinetic control. An increase in the quantity 
of biocatalyst would then promote the thermodynamic reaction, i.e. hydrolysis, to the detriment of the synthesis.

To complete this part of the study, it is noteworthy that the optimum quantity of biocatalyst for steps 1 and 2 was $875 \mathrm{mg}$, which represented the best compromise that comprised a high synthesis yield (87\% amide 3a synthesis and 24\% pseudo-ceramide 4 synthesis), an average production rate and a lower cost of Novozym ${ }^{\circledR} 435$.

\subsubsection{Effect of substrate concentration}

The effect of substrate concentration on both synthesis yield and production rate was investigated using various concentrations of acyl acceptor and acyl donor under stoichiometric conditions (Fig. 4). The results could not be interpreted when the substrate concentration was higher than $100 \mathrm{mM}$ due to the turbidity of the reaction mixture. This resulted in a partial solubility of the amphiphilic amide 3a produced in step 1, or used as a substrate in step 2 in the tert-amyl alcohol $/ n$-hexane mixture $(50: 50 \mathrm{v} / \mathrm{v})$ reaction solvent. Indeed this partial substrate solubility caused plugging problems in the packed-bed bioreactor, which precluded the development of a continuous process under these conditions.

\section{Fig. 4}

The use of substrate concentrations below $100 \mathrm{mM}$ during the first step appeared to have very little impact on the yield of amide 3a, which had an average value of $82 \%( \pm 5 \%)$. However, the production rate of amide 3a significantly and continuously increased in conjunction with the increase in substrate concentration, reaching $0.75 \mathrm{mmol} \mathrm{h}^{-1} \mathrm{~g}_{\text {biocatalyst }}{ }^{-1}\left(268 \mathrm{mg} \mathrm{h}^{-1}\right.$ g biocatalyst $\left.^{-1}\right)$ at $100 \mathrm{mM}$ of amino-diol $\mathbf{1}$ and fatty acid $\mathbf{2 a}$. Based on these results the amide production rate seemed to depend directly on the substrate concentration, while the yield was constant. Besides, $100 \mathrm{mM}$ is without contest the optimum substrate concentration as it 
corresponds to the highest concentration that could be used and didn't involve any problems with partial substrate solubility.

During the second step, the yield of pseudo-ceramide 4 followed a bell-shaped curve, reaching the best yield of $24 \%$ at $50 \mathrm{mM}$ of substrate but decreasing to 12 and $17 \%$ for substrate concentrations of 25 and $100 \mathrm{mM}$, respectively. The decrease in yield for the lowest substrate concentrations can be explained by a dilution of the substrates in the reaction medium. The decrease in yield for the highest substrate concentrations, however, is probably due to the decrease in enzyme/substrate ratio occurring in the catalytic bed when the substrate concentration is increased. Indeed, the thermodynamic equilibrium of the reaction may not be reached if this ratio is too low, and this could lead to a decrease in yield. Furthermore, the production rate of pseudo-ceramide 4 appeared to increase from 0.02 to $0.15 \mathrm{mmol} \mathrm{h}^{-1}$ g $_{\text {biocatalyst }}{ }^{-1}$ when the substrate concentration was increased from 25 to $75 \mathrm{mM}$. However, this rate was not enhanced by further increasing substrate concentration to $100 \mathrm{mM}$ i.e. the increase in substrate concentration did not compensate for the low yield obtained at this concentration. So, in contrast to what was previously described for amide 3a synthesis at step 1, the production rate at step 2 seems to depend on both substrate concentration and synthesis yield.

To conclude, $75 \mathrm{mM}$ was the optimum substrate concentration at step 2 for the simple reason that it provided the best compromise between a pseudo-ceramide yield close to the maximum (23\%) and an optimum production rate of $0.15 \mathrm{mmol} \mathrm{h}^{-1} \mathrm{~g}_{\text {biocatalyst }}{ }^{-1}\left(85 \mathrm{mg} \mathrm{h}^{-1} \mathrm{~g}_{\text {biocatalyst }}{ }^{-1}\right)$. Nevertheless, despite the high production rate obtained, these results were not satisfying enough in terms of pseudo-ceramide yield and we consequently decided to optimize our process by varying the substrate molar ratio in order to improve the yield in step 2 .

\subsubsection{Effect of substrate molar ratio}


The effect of substrate molar ratio on both the synthesis yield and the production rate of pseudo-ceramide 4 (step 2) was investigated using various myristic acid $\mathbf{2 b}$ concentrations and a fixed $N$-stearyl 3-amino-1,2-propanediol 3a concentration of $50 \mathrm{mM}$. The effect of increasing the amide 3a concentration was not tested due to the low solubility of this compound above $50 \mathrm{mM}$ and at $55^{\circ} \mathrm{C}$ in the tert-amyl alcohol $/ n$-hexane mixture $(50: 50 \mathrm{v} / \mathrm{v})$ reaction solvent. The substrate molar ratio of fatty acid $\mathbf{2} \mathbf{b}$ to amide $\mathbf{3 a}$ was varied within the range 1-5 (Fig. 5).

\section{Fig. 5}

Starting from values of $24 \%$ and $0.1 \mathrm{mmol} \mathrm{h}^{-1} \mathrm{~g}_{\text {biocatalyst }}{ }^{-1}$ at a molar ratio of 1 , the synthesis yield and production rate of pseudo-ceramide 4 were shown to increase concomitantly with the molar ratio, reaching $53 \%$ and $0.22 \mathrm{mmol} \mathrm{h}^{-1} \mathrm{~g}_{\text {biocatalyst }}{ }^{-1}\left(125 \mathrm{mg} \mathrm{h}^{-1}\right.$ g $\left._{\text {biocatalyst }}{ }^{-1}\right)$, respectively, at a molar ratio of 3 . This was the optimum value since a further increase in substrate molar ratio led to a fall in the values of these parameters to levels close to those obtained at a substrate molar ratio of 1 . These results are very similar to those described by $\mathrm{Xu}$ et al. with lipase-catalyzed interesterification reactions between triglycerides of rapeseed oil and capric acid, which demonstrated that the substrate molar ratio has a double function: a higher concentration of the acyl acceptor will push the reaction equilibrium toward the synthesis reaction and cause an increase in the theoretical maximum product yield, whereas a higher free fatty acid content will increase the possibility of an inhibition effect and require a longer reaction time to reach equilibrium [38]. Nevertheless, the results are interesting since the pseudo-ceramide synthesis yield was enhanced by a factor of 2 compared to all the previous results, and there was no decrease in the production rate.

Based on these encouraging results, we tested the best operational conditions identified so far: the flow rate was (only) doubled to $250 \mu 1 \mathrm{~min}^{-1}$, and we chose a substrate molar ratio of 
myristic acid 2b $(150 \mathrm{mM})$ to $N$-stearyl 3-amino-1,2-propanediol 3a $(50 \mathrm{mM})$ of 3, a stainless steel column $145 \mathrm{~mm}$ in length with a $5 \mathrm{~mm}$ inner diameter packed with $875 \mathrm{mg}$ of Novozym ${ }^{\circledR} 435$ to constitute the catalytic bed. Under these optimized conditions, pseudoceramide 4 was still produced with a yield of $54 \%$ but the production rate was doubled, reaching $0.46 \mathrm{mmol} \mathrm{h}^{-1} \mathrm{~g}_{\text {biocatalyst }}{ }^{-1}\left(261 \mathrm{mg} \mathrm{h}^{-1} \mathrm{~g}_{\text {biocatalyst }}{ }^{-1}\right)$.

To complete the study we wanted to scale-up our process. We thus decided to test various acyl donors in the first stage to evaluate the possibility that our process could be used for the synthesis of different pseudo-ceramides. The stability of Novozym ${ }^{\circledR} 435$, which was an essential condition prior to considering any further scale-up, was also investigated.

\subsection{Scale up of the process}

\subsubsection{Variation of the acyl donor nature}

In this part, the nature of the acyl donor was varied and evaluated at step 1 of the process. $\mathrm{N}$ acylation of 3-amino-1,2-propanediol was thus performed to compare five acyl donors, three saturated fatty acids of various chain length $(\mathrm{C} 12-\mathrm{C} 18)$ and two unsaturated $\mathrm{C} 18$ fatty acids.

The conditions previously optimized in terms of feed flow rate, substrate concentration, quantity of biocatalyst and bioreactor design were used in the process. Fig. 6 shows the yields of $N$-stearyl-, $N$-myristyl-, $N$-lauryl-, $N$-oleyl- and $N$-linoleyl-3-amino-1,2-propanediol (amides 3a, 3b, 3c, 3d and 3e, respectively) obtained after continuous Novozym ${ }^{\circledR}-435$ catalyzed $N$-acylation of 3-amino-1,2-propanediol $\mathbf{1}$ using stearic acid $\mathbf{2 a}$, myristic acid $\mathbf{2 b}$, lauric acid 2c, oleic acid $\mathbf{2 d}$ and linoleic acid $\mathbf{2 e}$ as acid donors, respectively.

\section{Fig. 6}

We observed that the yields obtained with saturated fatty acids $\mathbf{2 a}, \mathbf{2} \mathbf{b}$ and $\mathbf{2} \mathbf{c}$ ranged from $87 \%$ with lauric acid $\mathbf{2 c}$ to $95 \%$ with myristic acid $\mathbf{2 b}$, which indicated that acyl chain length 
had no significant effect on the amide yield. In addition, the use of unsaturated fatty acids $\mathbf{2 d}$ (C18:1) and 2e (C18:2) gave yields of $85 \%$ and $80 \%$, respectively. These results were barely lower than the yield of $92 \%$ obtained using a saturated C18 fatty acid, stearic acid 2a. Thus, the presence of one or two unsaturations on the carbon chain of the acyl donor did not appear to have a significant influence on the amide yield. To conclude this part of the study, an amide yield superior or equal to $80 \%$ was obtained with every fatty acid used as an acyl donor at step 1. Furthermore, this amide yield was shown to correspond to a mass production of amide that was higher than $800 \mathrm{mg} \mathrm{h}^{-1} \mathrm{~g}^{-1}$. From these results, it would clearly be feasible to produce a range of differently functionalized pseudo-ceramides with high yields starting from any of the five fatty acids tested in order to obtain compounds with various properties and applications.

\subsubsection{Stability of Novozym ${ }^{\circledR} 435$}

The operational stability of immobilized Candida antarctica lipase B (Novozym ${ }^{\circledR} 435$ ) in the continuous packed-bed bioreactor was studied over a 3-week period, during which the continuous $\mathrm{N}$-acylation of 3-amino-1,2-propanediol $\mathbf{1}$ was carried out using lauric acid $\mathbf{2 c}$ as the acyl donor (Fig. 7).

\section{Fig. 7}

Novozym ${ }^{\circledR} 435$ was found to be highly stable under these conditions since no decrease was observed in $N$-lauryl 3-amino-1,2-propanediol 3c yield after twenty-two days, with an average yield of $91 \% \pm 3 \%$; the productivity was of the order of $113 \mathrm{~g}$ of amide per $\mathrm{g}$ of Novozym ${ }^{\circledR}$ 435. This high stability may be partly related to the reaction solvent used. Indeed, water is produced during a reverse hydrolysis reaction so controlling water activity will consequently be of great importance, especially in a continuous process. According to the literature, a polar solvent such as tert-amyl alcohol can be used to control water activity in a continuous 
acylation process $[39,40]$. The tert-amyl alcohol polarity would thus enable the water produced to be evacuated, resulting in a partial drying of the immobilized lipase. As a result, optimal water activity would be maintained inside the reactor and optimum enzymatic activity would remain stable for a long time.

The excellent stability of Novozym ${ }^{\circledR} 435$ in the continuous packed-bed bioreactor allowed us to envisage further large scale pseudo-ceramide production given that the cost of the biocatalyst would not be a limiting factor.

\subsubsection{Scale up of the bioreactor design}

In order to perform a future scale-up of the packed-bed bioreactor to a pilot scale, the influence of reactor design on the yield and production rate of pseudo-ceramide 4 (step 2) was studied using two stainless steel columns of different geometries: column A was $125 \mathrm{~mm}$ in length with a $10 \mathrm{~mm}$ inner diameter and column $\mathrm{B}$ was $5 \mathrm{~mm}$ in length with a $50 \mathrm{~mm}$ inner diameter. Both columns were packed with $3300 \mathrm{mg}$ of Novozym ${ }^{\circledR} 435$ to constitute the catalytic bed, which was roughly a four-fold scale up in terms of the optimized quantity of $875 \mathrm{mg}$ of biocatalyst determined at the laboratory scale. In both cases, the flow rate was varied from 100 to $1200 \mu 1 \mathrm{~min}^{-1}$ to change the residence time of the substrates (Fig. 8).

\section{Fig. 8}

It is interesting to note that optimum pseudo-ceramide $\mathbf{4}$ yields of close to $30 \%$ were obtained in both cases at different flow rates, depending on the type of column used. Thus, the optimal yield was obtained for column A at a flow rate of $800 \mu 1 \mathrm{~min}^{-1}$ (residence time of 12.5 minutes), which corresponded to the highest production of $0.23 \mathrm{mmol} \mathrm{h}^{-1} \mathrm{~g}_{\text {biocatalyst }}{ }^{-1}$ (131 mg $\left.\mathrm{h}^{-1} \mathrm{~g}_{\text {biocatalyst }}{ }^{-1}\right)$, and the optimal yield was obtained for column B at a flow rate of $200 \mu \mathrm{min}^{-1}$ (residence time of 50 minutes), which corresponded to a production rate of only $0.05 \mathrm{mmol} \mathrm{h}^{-}$ 
${ }^{1} \mathrm{~g}_{\text {biocatalyst }}{ }^{-1}\left(28 \mathrm{mg} \mathrm{h}^{-1} \mathrm{~g}_{\text {biocatalyst }}{ }^{-1}\right)$. These results demonstrate that the use of a column with a

large diameter and a short length, such as column B, does not improve productivity.

495

In an enzymatic packed-bed bioreactor, two transport phenomena occur. The first involves the transfer of the substrate from the bulk liquid phase to the surface of the immobilized biocatalyst as a result of the formation of a fictitious laminar film. The second is the simultaneous diffusion of the substrate and its reaction within the biocatalyst particles. Internal diffusion limitations within porous carriers indicate that the slowest step is the penetration of the substrate into the interior of the catalyst particle. On the other hand, external mass transfer limitations occur if the rate of transport by diffusion through the laminar film is rate limiting [41]. According to the literature, external mass transfer in packedbed reactors can be improved by decreasing linear velocity, which is generally enhanced by decreasing the flow rate of the substrate or by changing the column reactor length-to-diameter ratio (L/d) [42-45]. In this work, for a given flow rate of $800 \mu 1 \mathrm{~min}^{-1}$, linear velocity values of 17 and $0.7 \mathrm{~mm} \mathrm{~s}^{-1}$ were obtained for columns $\mathrm{A}(\mathrm{L} / \mathrm{d}=12.5)$ and $\mathrm{B}(\mathrm{L} / \mathrm{d}=0.1)$, respectively. Thus, the very low linear velocity obtained for column B under these conditions increased the risk of external mass transfer limitation, which most likely explains the low yield obtained for column B (17\%) compared to column A (linear velocity 24 times higher than column B). Moreover, as described above, when we used a $145 \mathrm{~mm}$ long column with a $5 \mathrm{~mm}$ inner diameter, the optimal yield was obtained at a flow rate of $250 \mu 1 \mathrm{~min}^{-1}$ (see section 3.1.1), giving a linear velocity of $21 \mathrm{~mm} \mathrm{~s}^{-1}$. Interestingly, this is of the same order as the value obtained for column $\mathrm{A}\left(17 \mathrm{~mm} \mathrm{~s}^{-1}\right)$ and confirms that a high linear velocity is needed to minimize external mass transfer limitation and favor synthesis.

These results show that it is essential to use a long column with a small diameter such as column A (125 mm in length and $10 \mathrm{~mm}$ inner diameter) or the column used in other parts of this work (145 $\mathrm{mm}$ in length and $5 \mathrm{~mm}$ inner diameter). These columns both have a $\mathrm{L} / \mathrm{d}$ ratio 
within the range 12.5-29, which for this reason could be taken as an optimum L/d reference range to maintain an optimum yield and productivity in our continuous process. In addition, it is also necessary to have an adequate flow rate that produces a sufficiently high linear velocity (close to $20 \mathrm{~mm} \mathrm{~s}^{-1}$ ) to facilitate external mass transfer.

\subsubsection{Economic evaluation of the process}

The final objective of this work was to perform an economic evaluation of our continuous process under the optimal synthesis conditions for the two steps of the process. The economic viability of an enzymatic synthesis process is determined by several key variables including the manufacturing cost, the environmental cost, and the selling price and marketing cost for the product. The term "manufacturing cost" is used to describe the total costs involved in the manufacture of a synthetic product, which includes the cost of the biocatalyst, the chemicals, the solvents, the equipment, the energy and other operational costs. In our case, we observed the economic impact of three parameters which directly influence the manufacturing cost: the cost of the biocatalyst, the substrates and the organic solvents (reaction solvents and solvents used for the purification of the synthesis products).

In order to achieve a better assessment of the economic cost, we drew up a balance sheet of the two steps of the process. Under our optimized experimental conditions used at a 4-fold scale-up, an amide yield of $90 \%$ and a production rate of $1821 \mathrm{mg} \mathrm{h}^{-1}$ were obtained at step 1 ( $N$-acylation) using $3300 \mathrm{mg}$ of biocatalyst packed into the bioreactor. Assuming a biocatalyst lifespan of 3 weeks, a productivity of $918 \mathrm{~g}$ amide was obtained. Similarly, for step $2(O$ acylation), a pseudo-ceramide yield of $30 \%$ and a production rate of $432 \mathrm{mg} \mathrm{h}^{-1}$ were obtained (see section 3.2.3), which corresponds to a productivity of $218 \mathrm{~g}$ of pseudo-ceramide. To evaluate the cost effectiveness of the proposed process, the cost of pseudo-ceramide production was calculated by considering the second step as the limiting step of the process in 
terms of production and yield. So, given the price of the biocatalyst (Novozym $\left.{ }^{\circledR} 435\right)$, the

543 substrates (3-amino-1,2-propanediol 1, stearic acid 2a and myristic acid $\mathbf{2 b}$ ) and the solvents (tert-amyl alcohol, $n$-hexane and purification solvents), we calculated the cost of producing one $\mathrm{kg}$ of pseudo-ceramide under our optimal conditions: $21 €$ of biocatalyst, $351 €$ of substrates and 1,422 € of organic solvents. Suppliers quoted prices of about $2000 € / \mathrm{kg}$ for the

547 cheapest synthetic ceramide compounds. In consequence, the cost of the biocatalyst, 548 substrates and organic solvents represent $1 \%, 18 \%$ and $71 \%$ of the product price, respectively. The cost of the biocatalyst is usually one of the essential factors of the economic cost of an enzymatic synthesis process due to the high price of biocatalysts (Novozym ${ }^{\circledR} 435: 1100 € / \mathrm{kg}$ ). However, it is noteworthy that the pseudo-ceramide productivity of our continuous process in packed-bed bioreactor ( $\left.69 \mathrm{~g}_{\text {pseudo-ceramide }} \mathrm{g}_{\text {biocatalyst }}{ }^{-1}\right)$ was approximately 5 -fold higher than the results obtained in a process already developed for the synthesis of pseudo-ceramides in a batch bioreactor (15 $\left.\mathrm{g}_{\text {pseudo-ceramide }} \mathrm{g}_{\text {biocatalyst }}{ }^{-1}\right)$ [26], which shows that this method greatly reduces the economic cost of the biocatalyst. These results are thus encouraging in terms of the future development of this continuous process on a pilot scale but also demonstrate the need to recover and reuse the organic solvents as this could potentially have a significant impact on the cost effectiveness. Moreover, the production of pseudo-ceramides with a purity close to $99 \%$, like some commercial ceramides, would require the development of a purification method applicable on a large scale, such as liquid extraction or low pressure liquid chromatography.

\section{Conclusion}

In this work, we developed a new efficient continuous process for the selective Novozym ${ }^{\circledR}$ 435-catalyzed synthesis of pseudo-ceramides, conducted in a packed-bed bioreactor. To our knowledge, only batch bioreactors had indeed been used so far to develop the lipase-catalyzed synthesis of pseudo-ceramides or ceramides [11-13, 27]. Our process involved two steps for 
the optimization of the selective diacylation of 3-amino-1,2-propanediol 1 conducted in a tertamyl alcohol $/ n$-hexane mixture $(50: 50 \mathrm{v} / \mathrm{v})$, starting from two fatty acids as acyl donors: stearic acid 2a (step 1) and myristic acid $\mathbf{2 b}$ (step 2).

During the first step, the $N$-acylation of 3-amino-1,2-propanediol 1, the operational conditions of flow rate, quantity of biocatalyst and substrate concentration were optimized and an excellent synthesis yield of $92 \%$, associated with a very good production rate of $3.15 \mathrm{mmol} \mathrm{h}{ }^{-}$ ${ }^{1} \mathrm{~g}_{\text {biocatalyst }}{ }^{-1}$ (1128 $\mathrm{mg} \mathrm{h}^{-1} \mathrm{~g}_{\text {biocatalyst }}{ }^{-1}$ ) were obtained. During the second step, which involved the $O$-acylation of the $N$-stearyl 3-amino-1,2-propanediol 3a produced in the first step, we optimized the same operational conditions as in the first step together with the substrate molar ratio. Under the best conditions identified, the desired pseudo-ceramide, i.e. 1-O-myristyl,3$\mathrm{N}$-stearyl 3-amino-1,2-propanediol 4, was produced at a satisfying yield of $54 \%$ and a production rate of $0.46 \mathrm{mmol} \mathrm{h}^{-1} \mathrm{~g}_{\text {biocatalyst }}{ }^{-1}\left(261 \mathrm{mg} \mathrm{h}^{-1} \mathrm{~g}_{\text {biocatalyst }}{ }^{-1}\right)$.

These results clearly demonstrate that this two-step process has great potential for the industrial scale production of $\mathrm{N}, \mathrm{O}$-diacyl 3-amino-1,2-propanediol-type pseudo-ceramides, and in particular the 1-O-myristyl,3- $\mathrm{N}$-stearyl 3-amino-1,2-propanediol 4 synthesized in this work. This assumption is first strengthened by the fact that the productivity of pseudoceramide synthesis for this process was approximately improved by a factor 5, compared to the results obtained in a process already developed in a batch bioreactor [26]. On the other hand, we have shown that various fatty acids could be used as acyl donors in step 1 of our process, so its use for the synthesis of different pseudo-ceramides can be seriously envisaged.

Finally, in order to better assess the economic cost of pseudo-ceramide production we drew up a balance sheet of the two steps of the process at a 4-fold scale-up. So, given the suppliers' quoted prices of about $2000 € / \mathrm{kg}$ for the cheapest synthetic ceramide compounds, the cost of the biocatalyst, substrates and organic solvents used for synthesis and purification represented $1 \%, 18 \%$ and $71 \%$ of the product price, respectively. These results are encouraging in terms 
592 of the future development of this continuous process on a pilot scale, especially at the level of 593 the cost of the biocatalyst (Novozym ${ }^{\circledR} 435$ can operate for more than 3 weeks without a drop 594 in yield during step 1). But they also demonstrate the need to recover and reuse the organic 595 solvents and to work on the development of the purification process as this could potentially 596 have a significant impact on the cost effectiveness. 


\section{Acknowledgments}

598 This study was supported by the Centre National de la Recherche Scientifique and the French 599 ANR (National Research Agency) through the EXPENANTIO project (CP2P program: 600 Chimie et Procédés pour le Développement Durable).

601 


\section{References}

603 [1] L. Coderch, O. López, A. de la Maza, J.L. Parra, Am. J. Clin. Dermatol. 2 (2003) 107604 129.

605

[2] M. Kerscher, H.C. Korting, M. Schäfer-Korting, Eur. J. Dermatol. 1 (1991) 39-43.

606

607

[3] M. Fillet, M. Bentires-Alj, V. Deregowski, R. Greimers, J. Gielen, J. Piette, V. Bours, M.P. Merville, Biochem. Pharmacol. 10 (2003) 1633-1642.

[4] H. Garg, N. Francella, K.A. Tony, L.A. Augustine, J.J. Barchi Jr, J. Fantini, A. Puri, D.R. 609 Mootoo, R. Blumenthal, Antiviral Res. 1 (2008) 54-61.

610

[5] J.-F. Molina, Househ. Pers. Care Today. (2008) 12-15.

611

[6] S.H. Cho, L.J. Frew, P. Chandar, S.A. Madison, US Patent 5,476,671 A (1995).

612 [7] M. Philippe, D. Semeria, European Patent 884,305 A1 (1998).

613 [8] J.W.H. Smeets, P.G. Weber, US Patent 5,631,356 A (1997).

614 [9] H.-J. Ha, M.C. Hong, S.W. Ko, Y.W. Kim, W.K. Lee, J. Park, Bioorg. Med. Chem. Lett. 615 7 (2006) 1880-1883.

616

[10] E. Rochlin, US Patent CA2,373,286A1 (2000).

617

[11] M. Bakke, M. Takizawa, T. Sugai, H. Ohta, J. Org. Chem. 20 (1998) 6929-6938.

618

[12] L. Couturier, D. Taupin, F. Yvergnaux, J. Mol. Catal. B Enzym. 1 (2009) 29-33.

619

[13] R.M. De Pater, J.W.J. Lambers, J.W.H. Smeets, US Patent 561,004,0 A (1997).

620

[14] M.J. Haas, P.S. Fox, T.A. Foglia, Eur. J. Lipid Sci. Technol. 2 (2011) 168-179.

621

[15] M. Kapoor, M.N. Gupta, Process Biochem. 4 (2012) 555-569.

622

[16] B.M. Nestl, B.A. Nebel, B. Hauer, Curr. Opin. Chem. Biol. 2 (2011) 187-193.

623

[17] D. Sharma, B. Sharma, A.K. Shukla, Biotechnology. 1 (2011) 23-40.

624

[18] A. Tomin, G. Hornyánszky, K. Kupai, Z. Dorkó, L. Ürge, F. Darvas, L. Poppe, 625 Process Biochem. 6 (2010) 859-865.

626

[19] N. Doukyu, H. Ogino, Biochem. Eng. J. 3 (2010) 270-282. 
627 [20] M. Fernández-Pérez, C. Otero, Enzyme Microb. Technol. 6 (2001) 527-536.

628 [21] M. Fernández-Pérez, C. Otero, Enzyme Microb. Technol. 5 (2003) 650-660.

629 [22] T. Furutani, M. Furui, H. Ooshima, J. Kato, Enzyme Microb. Technol. 8 (1996) 578$630 \quad 584$

631 [23] V. Gotor, R. Brieva, F. Rebolledo, J. Chem. Soc. Chem. Commun. 14 (1988) 957632958.

[24] L.T. Kanerva, M. Kosonen, E. Vänttinen, T.T. Huuhtanen, M. Dahlqvist, M.M. Kady, 634 S.B. Christensen, Acta Chem. Scand. 11 (1992) 1101-1105.

635

[25] O. Torre, V. Gotor-Fernández, V. Gotor, Tetrahedron Asymmetry. 5 (2006) 860-866.

636

[26] L. Lassalle, F. Yvergnaux, European Patent 20,040,767,243 (2008).

637

[27] F. Le Joubioux, Y. Ben Henda, N. Bridiau, O. Achour, M. Graber, T. Maugard, J. 638 Mol. Catal. B Enzym. 85-86 (2013) 193-199.

639

[28] P.O. Syren, F. Le Joubioux, Y. Ben Henda, T. Maugard, K. Hult, M. Graber, Chem. 640 Cat. Chem. 5 (2013) 1842-1853.

641 [29] T. Takanami, H. Tokoro, D. Kato, S. Nishiyama, T. Sugai, Tetrahedron Lett. 46 642 (2005) 3291-3295.

643 [30] S.-W. Chang, J.-F. Shaw, C.-K. Yang, C.-J. Shieh, Process Biochem. 9 (2007) 1362644 1366.

645

[31] A. H-Kittikun, W. Kaewthong, B. Cheirsilp, Biochem. Eng. J. 1 (2008) 116-120.

646 [32] L. Couturier, F. Yvergnaux, Int. J. Cosmetic Sci. 31 (2009) 209-224.

647 [33] F. Le Joubioux, N. Bridiau, Y. Ben Henda, O. Achour, M. Graber, T. Maugard, J. $648 \quad$ Mol. Catal. B Enzym. (2013) 99-110.

649 [34] C. Bijani, PhD Thesis, 2010.

650 [35] R. Schnaar, A. Suzuki, P. Stanley, in: A. Varki, R.D. Cummings, J.D. Esko, H.H. 651 Freeze, P. Stanley, C.R. Bertozzi, G.W. Hart, M.E. Etzler (Eds.), Essentials of 
652

653

654

655

656

657

658

659

660

661

662

663

664

665

666

667

668

669

670

671

672

673

Glycobiology, 2nd edition, Cold Spring Harbor Laboratory Press. New York, 2009, pp. 129-142.

[36] P.W. Wertz, M.C. Miethke, S.A. Long, J.S. Strauss, D.T. Downing, J. Invest. Dermatol. 5 (1985) 410-412.

[37] W. Zheng, J. Kollmeyer, H. Symolon, A. Momin, E. Munter, E. Wang, S. Kelly, J.C. Allegood, Y. Liu, Q. Peng, H. Ramaraju, M.C. Sullards, M. Cabot, A.H. Merrill Jr, Biochim. Biophys. Acta. 12 (2006) 1864-1884.

[38] X. Xu, S. Balchen, C.-E. Høy, J. Adler-Nissen, J Am Oil Chem Soc. (1998) 15731579.

[39] S. Colombié, R.J. Tweddell, J.S. Condoret, A. Marty, Biotechnol. Bioeng. 3 (1998) $362-368$.

[40] W.F. Slotema, G. Sandoval, D. Guieysse, A.J.J. Straathof, A. Marty, Biotechnol. Bioeng. 6 (2003) 664-669.

[41] Y.H. Chew, C.T. Lee, M.R. Sarmidi, R.A. Aziz, F. Razali, Food Bioprod. Process. 4 (2008) 276-282.

[42] A.P. Ison, A.R. Macrae, C.G. Smith, J. Bosley, Biotechnol. Bioeng. 2 (1994) 122-130.

[43] Y. Iwasaki, T. Yamane, in: H.W. Gardner and T.M. Kuo (Eds.), Lipid biotechnology, Marcel Dekker, Inc. New York, 2002, pp. 421-422.

[44] M. Linde Damstrup, PhD Thesis, 2008.

[45] E. Szomanski, Proc. Third Australas. Conf. Hydraul. Fluid Mech. (1970) 117-123. 
675

676

677

678

679

680

681

682

683

684

685

686

687

688

689

690

691

692

693

694

695

696

Scheme 1. Two-step process for the selective enzymatic synthesis of 1-O,3- $\mathrm{N}$-diacyl 3-amino1,2-propanediol-type pseudo-ceramides catalyzed by Novozym ${ }^{\circledR} 435$ in a packed-bed bioreactor.

Fig. 1. Experimental setup for the continuous Novozym ${ }^{\circledR} 435$-catalyzed acylation reaction conducted in a packed-bed bioreactor system.

Fig. 2. Effect of flow rate on the synthesis yield $(\triangle)$ and production rate $(\bullet)$ of amide 3a (step 1, A) and pseudo-ceramide 4 (step 2, B). The reactions were carried out at $55^{\circ} \mathrm{C}$ in a tert-amyl alcohol $/ n$-hexane mixture $(50: 50 \mathrm{v} / \mathrm{v})$ using substrate concentrations of $100(\mathbf{A}$ : amino-diol $\mathbf{1}$ and stearic acid 2a) and $50 \mathrm{mM}$ (B: amide 3a and myristic acid 2b) under stoichiometric conditions. Stainless steel columns $95 \mathrm{~mm}$ in length with an inner diameter of $5 \mathrm{~mm}(\mathbf{A})$, and $145 \mathrm{~mm}$ in length with a $5 \mathrm{~mm}$ inner diameter (B), were packed with 430 (A) and $875 \mathrm{mg}$ (B) of Novozym ${ }^{\circledR} 435$ to constitute the catalytic beds.

Fig. 3. Effect of the quantity of biocatalyst on the synthesis yield $(\triangle)$ and production rate $(\bullet)$ of amide 3a (step 1, A) and pseudo-ceramide 4 (step 2, B). The reactions were carried out at $55^{\circ} \mathrm{C}$ in a tert-amyl alcohol $/ n$-hexane mixture $(50: 50 \mathrm{v} / \mathrm{v})$, at a flow rate of $125 \mu 1 \mathrm{~min}^{-1}$ and substrate concentrations of 100 (A: amino-diol 1 and stearic acid 2a) and $50 \mathrm{mM}$ (B: amide 3a and myristic acid 2b) under stoichiometric conditions. Stainless steel columns with an inner diameter of $5 \mathrm{~mm}$ and of variable length, in which various quantities of Novozym ${ }^{\circledR} 435$ could be packed, were used as the catalytic beds.

Fig. 4. Effect of substrate concentration on the synthesis yield $(\triangle)$ and production rate $(\bullet)$ of amide 3a (step 1, A) and pseudo-ceramide 4 (step 2, B). The reactions were carried out at $55^{\circ} \mathrm{C}$ in a tert-amyl alcohol $/ n$-hexane mixture $(50: 50 \mathrm{v} / \mathrm{v})$ at a flow rate of $125 \mu 1 \mathrm{~min}^{-1}$ and 
697

698

699

700

701

702

703

704

705

706

707

708

709

710

711

712

713

714

715

716

717

718

719

various substrate concentrations, from 10 to $100 \mathrm{mM}$, under stoichiometric conditions (A: amino-diol $\mathbf{1}$ and stearic acid 2a; $\mathbf{B}$ : amide 3a and myristic acid 2b). A stainless steel column $145 \mathrm{~mm}$ in length with an inner diameter of $5 \mathrm{~mm}$ was packed with $875 \mathrm{mg}$ of Novozym ${ }^{\circledR} 435$ to constitute the catalytic bed.

Fig. 5. Effect of substrate molar ratio on the synthesis yield $(\triangle)$ and production rate $(\bullet)$ of pseudo-ceramide 4 (step 2). The reactions were carried out at $55^{\circ} \mathrm{C}$ in a tert-amyl alcohol $/ n$ hexane mixture $(50: 50 \mathrm{v} / \mathrm{v})$ at a flow rate of $125 \mu 1 \mathrm{~min}^{-1}$, various substrate molar ratios from 1 to 5 and a fixed amide $3 \mathbf{a}$ concentration of $50 \mathrm{mM}$. A stainless steel column $145 \mathrm{~mm}$ in length with an inner diameter of $5 \mathrm{~mm}$ was packed with $875 \mathrm{mg}$ of Novozym ${ }^{\circledR} 435$ to constitute the catalytic bed.

Fig. 6. Effect of the nature of the fatty acid used as an acyl donor on the synthesis yield (histogram) and production rate $(\bullet)$ of the amide (step 1), using 3-amino-1,2-propanediol 1 as the acyl acceptor and various fatty acids as acyl donors. The reactions were carried out at $55^{\circ} \mathrm{C}$ in a tert-amyl alcohol $/ n$-hexane mixture $(50: 50 \mathrm{v} / \mathrm{v})$ at a flow rate of $500 \mu 1 \mathrm{~min}^{-1}$ and a substrate concentration of $100 \mathrm{mM}$, under stoichiometric conditions. A stainless steel column $145 \mathrm{~mm}$ in length with an inner diameter of $5 \mathrm{~mm}$ was packed with $875 \mathrm{mg}$ of Novozym ${ }^{\circledR} 435$ to constitute the catalytic bed.

Fig. 7. Continuous Novozym ${ }^{\circledR} 435$-catalyzed synthesis of amide 3c (step 1) over a 3 week period using 3-amino-1,2-propanediol $\mathbf{1}$ as the acyl acceptor and lauric acid $\mathbf{2 c}$ as the acyl donor. The reaction was carried out at $55^{\circ} \mathrm{C}$ in a tert-amyl alcohol $/ n$-hexane mixture $(50: 50$ $\mathrm{v} / \mathrm{v}$ ), at a flow rate of $250 \mu \mathrm{l} \mathrm{min}^{-1}$ and a substrate concentration of $50 \mathrm{mM}$, under stoichiometric conditions. A stainless steel column $145 \mathrm{~mm}$ in length with an inner diameter of $5 \mathrm{~mm}$ was packed with $875 \mathrm{mg}$ of Novozym ${ }^{\circledR} 435$ to constitute the catalytic bed. 
720 Fig. 8. Effect of reactor design on the synthesis yield $(\triangle)$ and production rate $(\bullet)$ of pseudo721 ceramide 4 (step 2) using column A (125 mm in length and $10 \mathrm{~mm}$ inner diameter) or 722 column B (5 mm in length and $50 \mathrm{~mm}$ inner diameter). The reactions were carried out at $55^{\circ} \mathrm{C}$ 723 in a tert-amyl alcohol $/ n$-hexane mixture $(50: 50 \mathrm{v} / \mathrm{v})$ with $150 \mathrm{mM}$ myristic acid $\mathbf{2 b}$ and 50 $724 \mathrm{mM}$ amide 3a. Stainless steel columns $125 \mathrm{~mm}$ in length with a $10 \mathrm{~mm}$ inner diameter (A) 725 and $5 \mathrm{~mm}$ in length with a $50 \mathrm{~mm}$ inner diameter $(\mathbf{B})$ were packed with $3300 \mathrm{mg}$ of 726 Novozym $^{\circledR} 435$ to constitute the catalytic beds. 
Step 1:

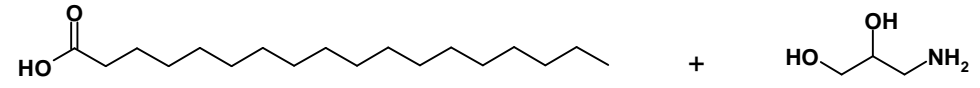

Stearic acid 2a | 3-amino-1,2-propanediol 1

Novozym ${ }^{\oplus} 45$ in

packed-bed bioreactor $\longrightarrow \mathrm{H}_{2} \mathrm{O}$

Step 2:
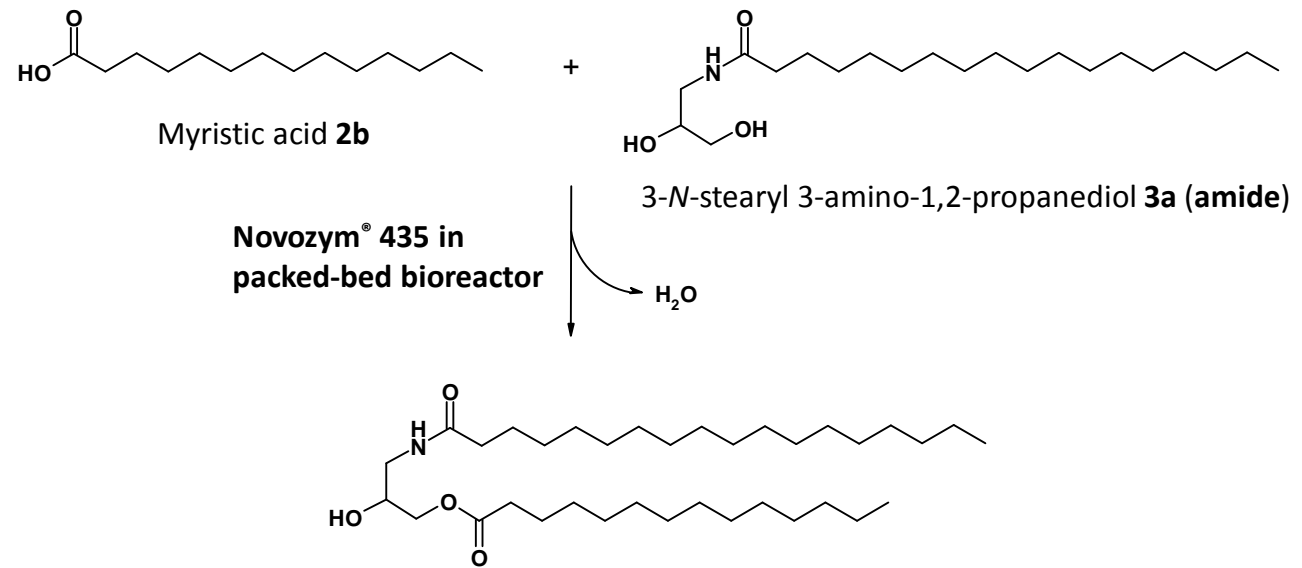

Scheme 1. 


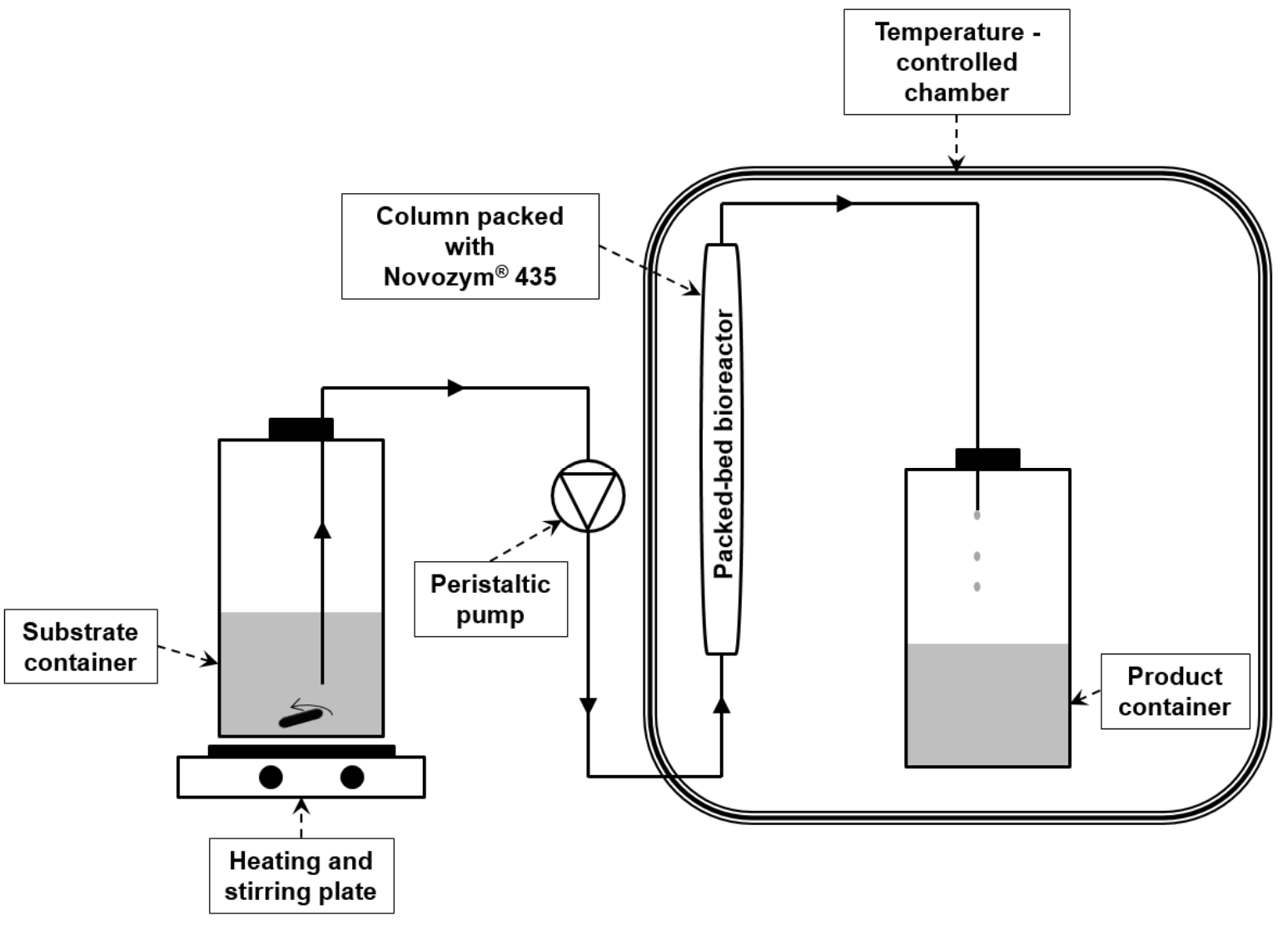

731 Fig. 1. 

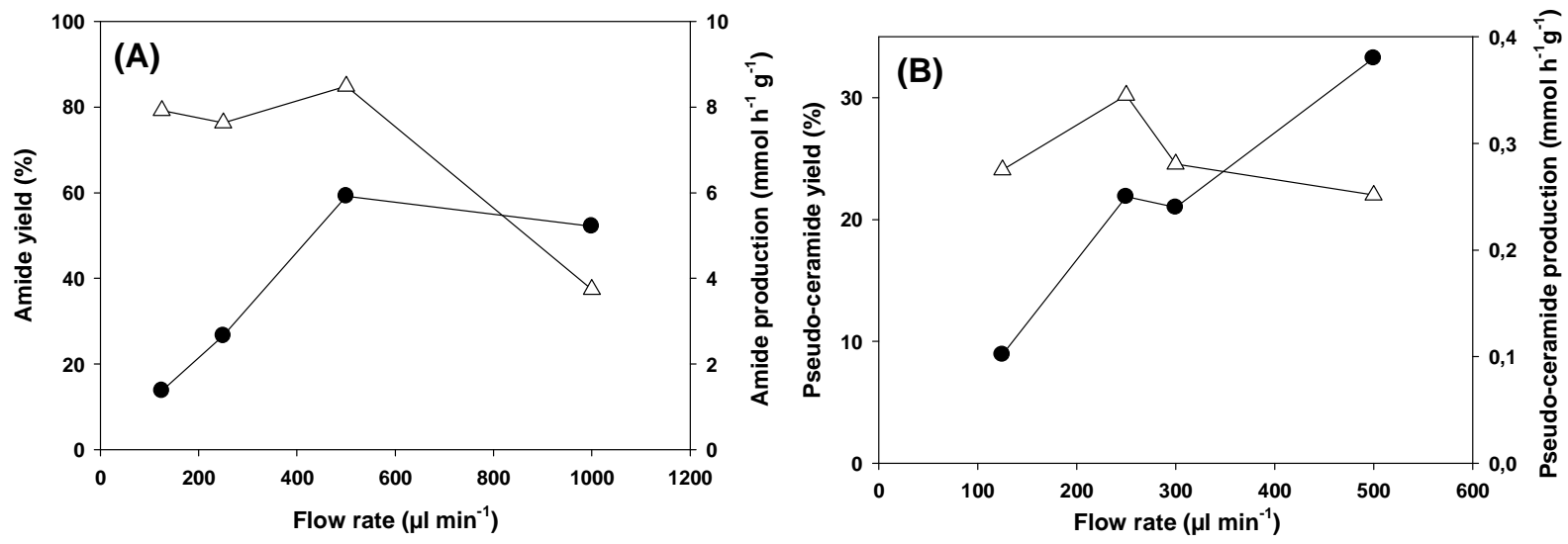

Fig. 2. 

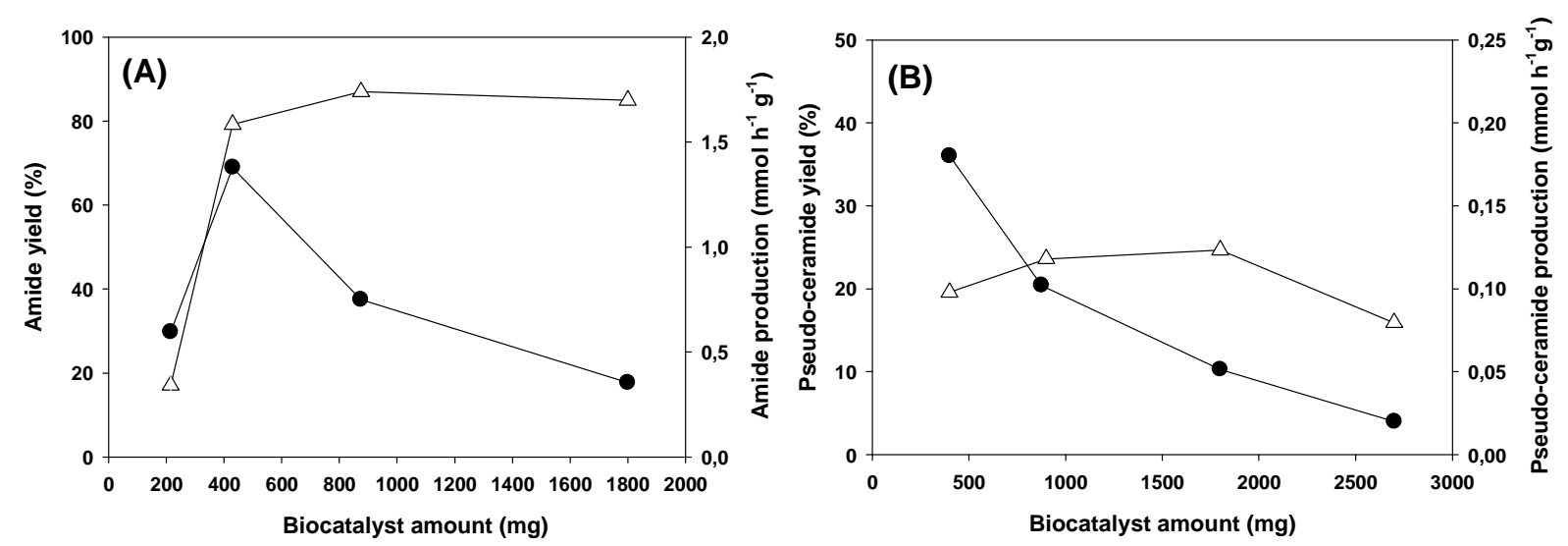

$735 \quad$ Fig. 3. 

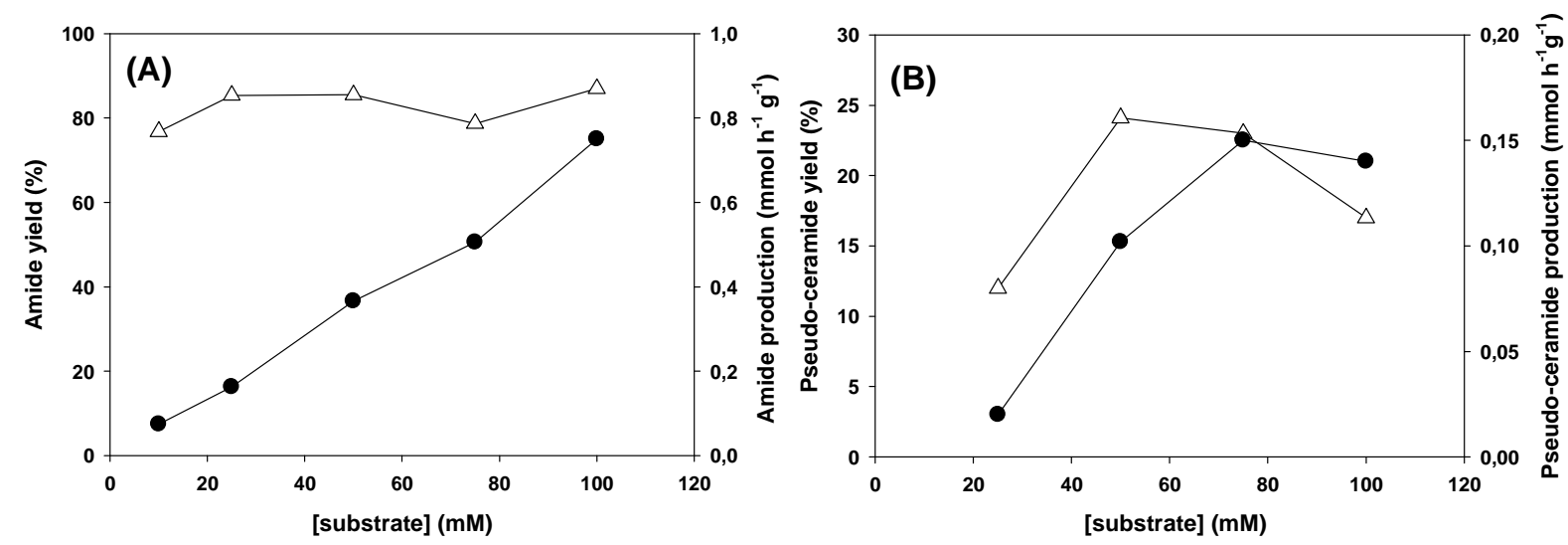

$737 \quad$ Fig. 4. 


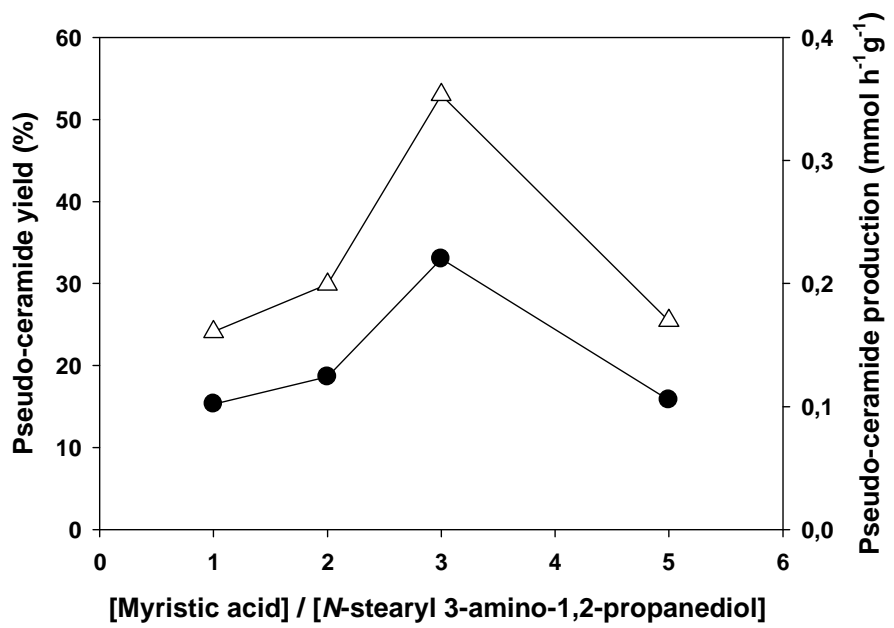

$739 \quad$ Fig. 5. 


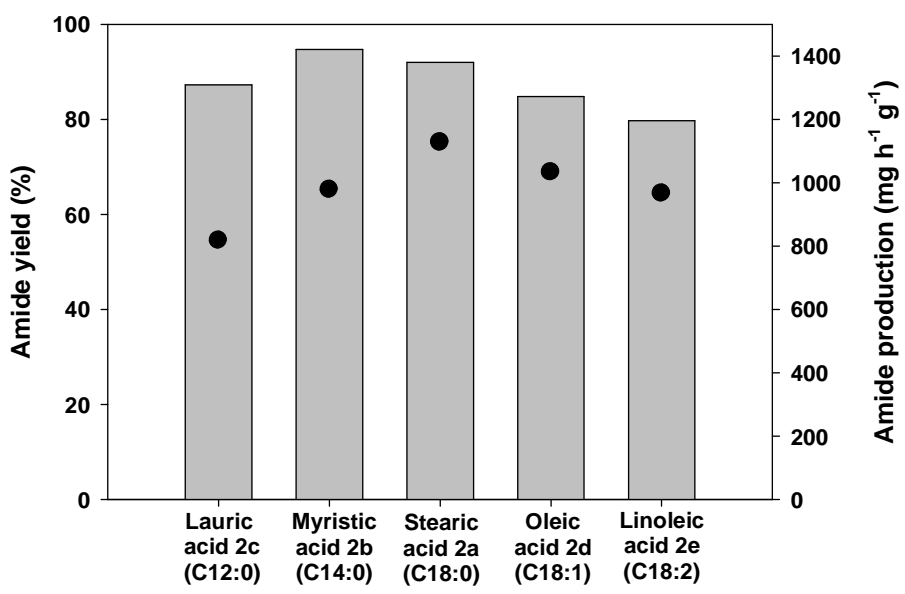

$741 \quad$ Fig. 6. 


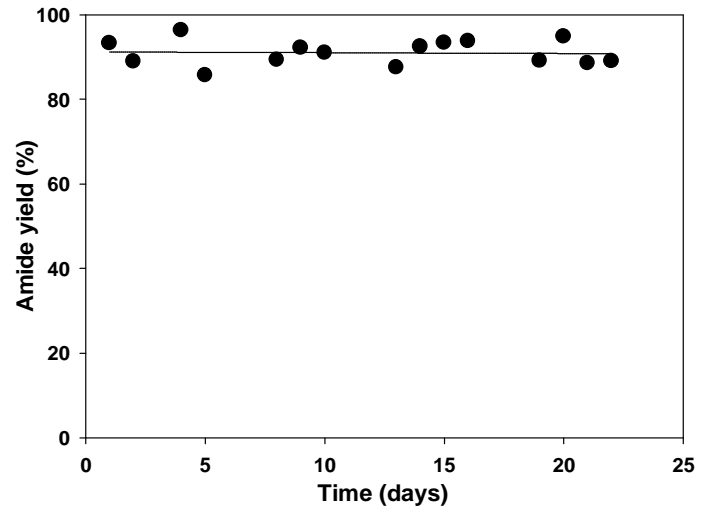

$743 \quad$ Fig. 7. 


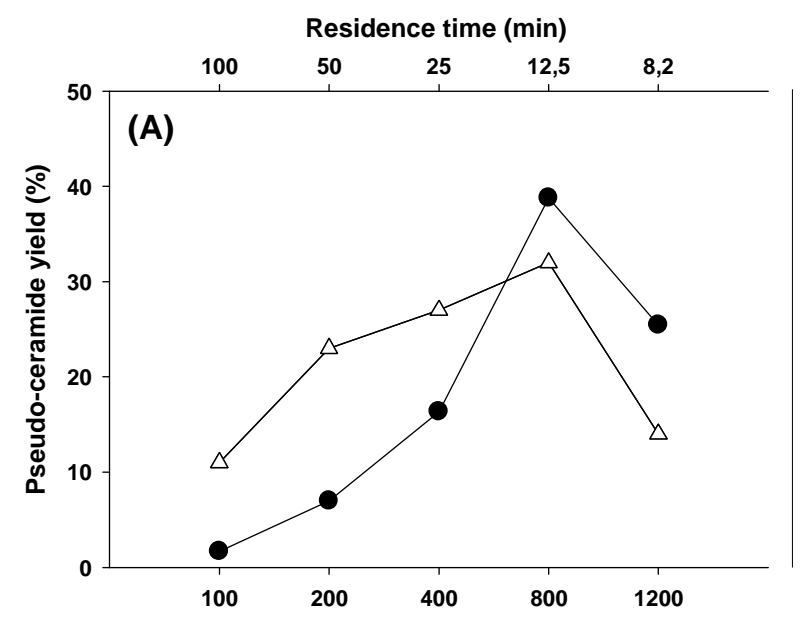

744

Flow rate $\left(\mu \mathrm{l} \min ^{-1}\right)$

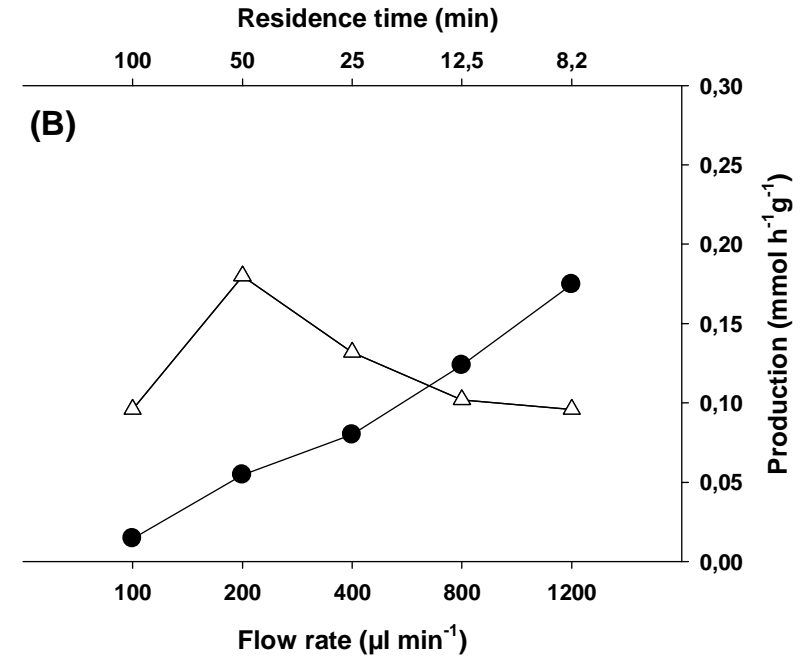

745 Fig. 8. 


\section{Table 1}

749 Elution gradient for HPLC analysis

\begin{tabular}{ccc}
\hline $\begin{array}{c}\text { Time } \\
(\mathrm{min})\end{array}$ & $\begin{array}{c}\text { Solvent A: acetonitrile/water/acetic } \\
\text { acid }(77: 23: 0.1 \mathrm{v} / \mathrm{v} / \mathrm{v})\end{array}$ & $\begin{array}{c}\text { Solvent B: methanol/acetic acid } \\
(\%)\end{array}$ \\
\hline 0 & 100 & $(\%)$ \\
90 & 100 & 0 \\
93 & 0 & 0 \\
143 & 0 & 100 \\
145 & 100 & 100 \\
153 & 100 & 0 \\
\hline
\end{tabular}

750

751 